\title{
Bondeliv på Broagerland
}

\section{Gårdejer Andreas Andresens erindringer fra Skelde}

\author{
Ved Hans Schultz Hansen
}

Andreas Andresen fra Skelde på Broagerland levede fra 1842 til 1914 og oplevede således som barn og ungt menneske den danske tid til 1864 og som voksen størstedelen af fremmedherredømmet. Han voksede op på slægtsgården Rojhus, som han overtog i 1872. Gården var $i$ hans tid på knap 40 ha god jord. Andresen tilhørte i udpræget grad den danske bevægelses elite af højskoleinspirerede gårdmænd. Han var således en fremtrædende skikkelse i Broagerlands og Sundeveds nationale $\mathrm{og} ø$ konomiske organisationer, ligesom han medvirkede til oprettelsen af frimenigheden på Sundeved. I sine erindringer skildrer han dette arbejde. Den fyldige omtale af forbedringerne inden for landbruget afspejler egnens position som et foregangsområde i Nordslesvig. Endelig bringer Andresen en række skitser af befolkningens dagligliv og tænkemåde $i$ en forandringsrig periode. Erindringerne er nedskrevet omkring 1910, og de dækker tiden frem til ca. 1905.

\section{Slægten}

Jeg har ofte tænkt paa at ville optegne de af mine Livserindringer, som muligt vil kunne have Interesse for mine Børn; men dels paa Grund af formentlig Mangel paa Tid og dels paa Grund af Efterladenhed har jeg ikke faaet begyndt paa det før nu i min fremrykkede Alder, da en Del er gaaet mig af Minde.

Jeg vil nu først begynde med at gjøre Rede for min Slægt saa langt tilbage, som jeg kan; men dette er rigtig nok ikke ret langt. Jeg ved kun med Bestemthed, at min Faders Farfader, som hed Peter Andresen, levede paa den Tid, da Jordfællesskabet blev ophævet her $i$ byen, og alle de herværende Udflyttergaarde, som før den Tid laa i Byen, byggedes op paa de til dem anviste Jordlodder paa Byens Udmark'. Det var i Aarene 1777 og 78, at dette skete. Gaarden laa den Gang, hvor nu Jens Veggerslev boer, altsaa lige neden for Mejeriet. Gaarden har siden den Tid været i min Slægts Eje, men om dette har været Tilfældet ret længe før min Tid, har jeg aldrig faaet noget at vide om. Peter Andresen maa have været en ung Mand paa denne Tid, da hans Søn, min Farfader, Andreas Andresen, der som Fæstearving, altsaa vist nok ældste Søn, fik Gaarden efter ham, var født 1780. Peter Andresens Hustru hed Catharina Dorothea, født Iversen, men hvor hun stammede fra, har jeg ingen Oplysninger om $^{2}$. Hvor langt deres Ægteskab har været, det ved jeg ikke; men han er rimeligvis død noget tidlig, da hans Enke er bleven gift med 
Peter Petersen fra Surlykke i Dybbøl Sogn, som blev Sættemand (Aartidsmand) $)^{3}$ paa Gaarden indtil Aaret $1808 \ldots$

Som nævnt fik min Farfader, Andreas Andresen Gaarden i 1808. Han havde været Soldat i 7 Aar, nemlig fra 1798 til 1805, hvilket ses af en Afskrift af en

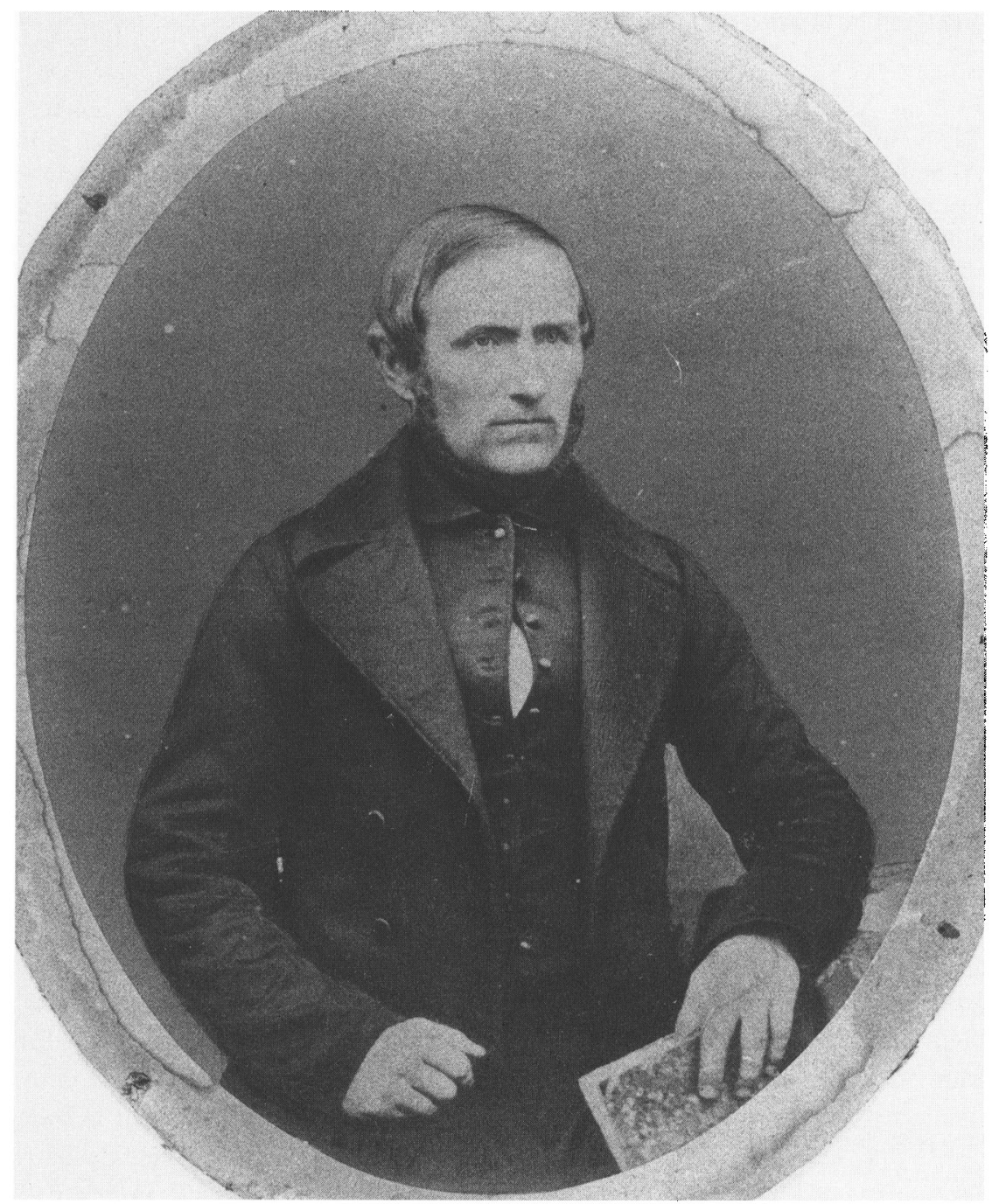

Andreas Andresens far Hans Chr.Andresen levede fra 1818 til 1869. Fra 1839 til kort for sin dod drev han slagtsgården Røjhus på Skeldemark. Af hans bevarede dagbogs- og regnskabsoptegnelser fremgår, at han var en driftig landmand, der $i$ lebet af 1850'erne forlod den ensidige kornavl til fordel for en mere alsidig produktion med fremstillingen af smor som et vigtigt element. Fot. af H.Kriegsmann, Flensborg, $i$ privateje. 
Ansøgning til Kongen i 1810 om at blive fri for yderligere Indkaldelse. Om han slap derfor, ses ikke deraf. Min Fader har fortalt, at han laa i længere Tid i Eiderstedt, og da fik han en Slags Feber, som blev ved at holde sig til Tid efter anden med Rysten, omtrent som Koldfeber, og som han kaldte "Irrestejs Koeld«. (Ejderstedter Koldfeber). Min Fader havde ikke sjældent en saadan Rysten paa sig, naar han gik i Seng om Aftenen, og jeg har tidligere ogsaa havt den en Gang imellem, uden at jeg kan sige, at det har havt ubehagelige Følger. Jeg nævner kun dette som et Eksempel paa, hvad der kan være arveligt $\mathrm{i}$ en Familie. Min Farfader døde d. 11. Januar 1839 omtr. 59 Aar gammel, efter flere Aars Svagelighed af Vandsot.

Han var 2 Gange gift, første Gang med Ingeborg Iversen, med hvem han vist nok ingen Børn har haft; anden Gang var han gift med Margretha Juhler fra Mølmark. ... Min Farfader merglede Gaarden, jeg antager før og i 1820erne. Dette maa lige som andre Steder have gjort god Virkning, for jeg har hørt af min Farbroder, Peter Andresen, at Kornet gav stærkt i Skjæppen derefter. Hans anden Kone, min Farmoder, døde d. 22.5.1849. Hende kan jeg godt mindes, og navnlig husker jeg godt den Dag, hun døde. Jeg havde været i Skole, og min Søster Sophie (5 Aar gammel) fortalte mig det triumferende, da jeg kom hjem, som en Nyhed hun vidste førend jeg. Hun sad paa sin Stol og døde af et Slagtilfælde. Min Farfader gjorde Testamente i 1838, et Par Maaneders Tid, før han døde; af dette sees, at han efter den Tids Forhold har siddet i ret gode Omstændigheder, idet han har angivet, at have 1100 Rigsdaler Courant (3960 Rigsmark) paa Renter.

I sit andet Egteskab havde han 4 Børn, nemlig min Fader, Hans Christian Andresen, født d. 14. Februar 1818, Peter Andresen, født 1820, Ingeborg Andresen, født 1824, og Jørgen Christian Andresen, født 1834. En Søn, Jens Christian, døde tidligt.

Min Fader fik Gaarden efter min Farfaders Død i 1839. Han blev gift d. 26. Juni 1840 med Sophia Maria Tychsen, Datter af Gaardejer Tyge Tychsen og hans Kone Maria Sophia, født Iversen her paa Skeldemark. Min nys nævnte Mormoder var en Datter af Gaardejer Rasmus Iversen, som ejede Jens Peter Clausens Gaard nordligst i Byen. Min Moder var født d. 8. Maj 1820. ...

\section{Barndom}

Jeg er født den 20. Marts 1842 og er ældste Barn af min Faders første Ægteskab. Min Søster, Maria Sophia var født den 20. Juli 1844, og min Broder, Tyge, er født den 9. Juli 1848. Min Moder døde den 20. Decbr. 1850 
og blev begravet paa Juleaftensdag. Hun døde af Nervefeber (Tyfus), som de fleste af Husets Folk ogsaa havde havt. Jeg var nærværende i hendes Dødsstund ligesom ogsaa min Fader og min Mormoder. Paa en Gang sagde hun: "Jeg dør, jeg dør!« Saa gav min Mormoder hende en Skefuld Medicin. Derefter blev hun helt rolig. Da sagde min Mormoder: "Er det nu bedre? « Men derpaa svarede hun ikke, og da de saa nærmere efter, var hun død.

Det er kun nogle enkelte Smaatræk, jeg kan mindes om hende: En Vinterdag stod hun og vaskede sig i det gamle Bakhus, og inden hun kom ind, var hendes Haar frosset stivt. Det er fra dette lille Træk, hvor hun gik med det frosne Haar hængende ned om sig og saa fra hendes Dødsleje, at jeg har en Forestilling om hendes Udseende. Saa kan jeg huske en Søndag Formiddag, at hun stod og klædte mig paa, mens jeg stod paa en Stol foran nogle Billeder, som hang paa Væggen mellem Stueuhret og Vinduet ud til Blomsterhaven ved Gaardspladsen. Jeg spøgte da og sagde om et Billede, at det var Jesus, der var afbildet, hvilket ogsaa var Tilfældet. Da sagde hun: "Det maa Du ikke sige." Dette maa have præntet sig fast $\mathrm{i}$ min Bevidsthed, for jeg kan godt mindes, at jeg i mange Aar ikke nævnte Jesus-Navnet uden med en vis Varsomhed og ofte kom i Tanker om min Moder derved. Hendes Mening har aabenbart været den, at vi Børn skulde vænnes til ikke at bruge dette Navn tankeløst. ...

I 1851 i August Maaned giftede min Fader sig med min Moster Anna Maria, den yngste af min Moders Søskende. Jeg husker godt deres Bryllupsdag, og jeg kan navnlig mindes, at jeg sammen med nogle andre Drenge havde drukket vel meget af Vinen, saa jeg maatte i Seng i Karlekammeret, og jeg kom ikke op før sent om Aftenen, hvilket jeg fortrød saa meget for Musikens Skyld, som jeg gik Glip af. I min Faders andet Ægteskab fødtes en Datter, Sophia Maria, den 3. Februar 1853. ...

\section{Skolegang}

Jeg kom i Skole hos Lærer Vesterlund ${ }^{4}$ i Foraaret 1848, men Vinteren efter blev jeg hjemme paa Grund af den lange Skolevej. Jeg fik saa Undervisning af min Fader, som fik nogen Vejledning deri af Vesterlund. Den Gang var Skolen, hvad man kalder enklasset, saa vi undervistes alle af een Lærer, skjønt Børneantallet var stort; det steg omsider til imellem 120 og 130. Saa blev Skolen bygget større og blev toklasset. Den første Andenlærer, vi havde, hed Lammers ${ }^{5}$ og var fra Slesvig. Det var det Aar, jeg blev konfirmeret, nemlig 1858. Lammers har senere været Lærer i Horsens.

Vi fik lidt Undervisning i Tysk (1/2 Time hver Dag), men dette ophørte 
efter Krigen i 1848-49-50; men der blev ligesom tidligere givet privat Tysk Undervisning 4 Aftener om Ugen efter endt Skoletid, saakaldet »Efterstund«. Dette gik jeg stadig med til, da jeg var vokset noget til. Vi lærte ret godt at læse og skrive Tysk, men fik ikke megen Øvelse i at tale det, skjønt vi om Vinteren skulde give et $Æ$ ble i Mulkt, hver Gang vi talte Dansk. Naar der saa var indkommet en Del Æbler, delte Læreren dem imellem os alle. Vi havde selv Tællelys med til Belysning. Det var gjerne fornøjeligt $\mathrm{i}$ disse Timer, vel mest, fordi Læreren var venligere end om Dagen, formodentlig af den Grund, at han ikke havde saa mange at arbejde med. Vesterlund var efter den Tids Forhold en ret dygtig Lærer, og han passede sin Skole med stor Omhu. Det var ham saa meget om at gjøre, at vi var godt hjemme i Religionen, og naar det ikke rigtig vilde gaa om Morgenen med Katekisationen, saa kunde han nok sige: "Jeg gider rigtig ikke snakke længere med Jer, Børn.« Eller: »Jeg er saa kjed af Jer som Kat af Sennep.« Og saa holdt han op.

Af Lærebøger havde vi, dog først efter Krigen, Balslevs Luthers Katekismus, Bircks Bibelhistorie og Bircks Læsebog (lille og store Birck kaldte vi dem), samt Ny Testamente. Af Regnebøger havde vi først en meget god, men tysk: Kroymanns Regnebog. Men i Halvtredserne blev Rigsmøntberegningen og Decimalregning indført, saa vi maatte have nye danske Regnebøger, nemlig Grünfelds 1ste, 2den og 3die Del; det var ogsaa en god Regnebog. Tegning havde vi ikke noget af, undtagen hvem der vilde kunde en Time i Ugen faa Lov til at tegne Landkort efter nogle mindre Kort, som var forhaanden til dette Brug. Af denne Tegning har jeg mit meste Kjendskab til UdenlandsGeografi. I Geografi havde vi en Time i hver Uge, men det indskrænkede sig til, at vi lærte at opregne de forskjellige Landes Bjergkæder, Floder, Havbugter, Søer, Stæder m.m. Om Landenes Natur, Frembringelser, Befolkning m.m. fik vi ikke ret meget at vide. Af Vægkort havde vi først kun et Danmarkskort, men senere fik vi et over Europa og et over Palæstina. I Bircks Læsebog var der dog ogsaa noget Geografi, som vi læste. Desuden var der ogsaa Fortællinger af Fædrelandshistorien, som vi havde en Time i hver Uge.

Det var ikke meget, Læreren fortalte os i de forskjellige Fag: det meste bestod i Gjengivelse af det, vi læste, saa det maa siges, at Undervisningen i mange Henseender var noget »tør«. Men naar Læreren en Gang imellem var i særlig godt Humør, saa kunde der dog nok vanke et og andet ud over det dagligdags. Saa var der villige Øren. I Skrivning havde vi, foruden Skjønskrivning i Skrivebogen, en Time i Ugen Stileskrivning, som vi kaldte »Opsætning«. Da skulde vi ud af Hovedet skrive om et eller andet opgivet Emne, men dette interesserede os ikke meget. Derimod havde vi en Time om Ugen Brevskrivning; dette var vi mere med paa, skjønt den traditionelle Begyndelse næsten altid var: Jeg melder dig i dette Brev, at jeg er ved god Sundhed, og det 
samme ønsker jeg ogsaa at høre fra dig igjen. Al Skrivningen, undtagen Skjønskrivningen, var paa Tavle. Skrivebøgerne syede min Fader til mig og mine Søskende af ulinieret Skrivepapir. Der var nok Skrivebøger at faa tilkjøbs, men de var dyrere og sædvanligvis af daarligere papir. Diktat havde vi ikke.

Jeg kan mindes, at Pastor Schleppegrell ${ }^{6}$ satte os i en pinlig Forlegenhed en Dag i det sidste Aar, jeg gik i Skole, da han holdt Eksamen i vor Skole. Han fortalte et Eventyr, som vi skulde skrive op bag efter. "Skulde jeg fortælle det en Gang til?« sagde han, da han havde endt det. "Nej, det svækker Hukommelsen«, sagde han, og saa maatte vi til det. Det var noget aldeles nyt for os. Jeg reddede mig for øvrigt godt ud af Situationen, idet jeg kun havde én Fejl, den nemlig, at jeg et Sted havde skrevet »hverandre" i Stedet for whinanden «. Æventyret var om Edderkoppen og Podagraen. Jeg fik den Dag saa stor Ros af Præsten, at jeg næsten var forlegen derved, og jeg fik nogen Tid derefter Skjænd af min Fader, fordi jeg ikke havde fortalt ham dette. Han havde nemlig hørt det af en anden Mand her i Byen, som ogsaa havde Børn i Skolen.

Naturvidenskab fik vi kun meget lidt at vide af i Skolen. Vi lærte, at Jorden bestod af 4 Elementer, nemlig: Jord, Luft, Ild og Vand, og det indre af Jorden var faste Stene. Ved Konfirmationsundervisningen kom Pastor Schleppegrell en Dag til at fortælle os, at det indre af Jorden var Ild, og at der kun var en fast Skorpe, ca. 6 Mil tyk uden om dette Ildbaal. Denne Nyhed var os saa overraskende, at vi ikke kunde nægte os den Fornøjelse at fortælle Læreren den. Men han svarede: "Ja, hvor ved han 'et, har han kanske væ't der?« Ellers var vi ikke meget fortrolige med vor Lærer; han var egentlig streng, men misbrugte dog ikke sin Myndighed ret ofte.

Vi havde, saa længe jeg gik i Skole, den »evangelisk-kristelige Salmebog«, hvoraf vi sang en Salme om Morgenen og lærte Aar efter andet en vis Række Salmer udenad, men bestandig de samme. Ligeledes havde vi nogle bestemte Morgen-, Middag- og Aftenbønner, som vi skiftevis bad hver en af til de fastsatte Tider hver Dag. I Halvtredserne blev K. Karstensens ${ }^{7}$ Sangbog indført i Skolen, af hvilken vi sang flere Sange en bestemt Dag i hver Uge. Læreren var ikke nogen fremragende Sanger, saa det var nok ikke saa ganske rigtig fat med nogle af de ny Melodier, han lærte os. Trods alle de her næunte Ulemper ved Undervisningen, som jo for en stor Del maa tilskrives den Tids Methode, maa det dog siges, at Vesterlund var en dygtig Lærer, som levede for sin Skole og passede den godt, og Skelde Skole havde i den Tid Ord for at være en af de bedste i Sognet. Om det var af denne Grund, eller det var en ældre Tradition, at Børnene fra vor Skole altid stod øverst paa Kirkegangen ved Konfirmationen, det ved jeg ikke. Vesterlund var Lærer her fra først i Trediver- 
ne til 1862 og blev afløst af daværende Andenlærer, Diderik Holst ${ }^{8}$ fra Bredsted-Egnen. Han var Førstelærer her til 1. Okt. 1902. Han blev, anden Gang, gift med Vesterlunds Datter, Anne Marie i 1866.

\section{Treårskrigen og folkeligt-nationale tilstande 0.1850}

Fra Treårskrigens Tid kan jeg kun mindes nogle faa Begivenheder. Der var en Dag nogle tyske Soldater herude, som laa indkvarterede i Byen. De stjal Æg i Hønsehuset, og da de gik ud over Mosen hjem, skulde Æggene fortæres raa; da var der en af dem, som havde faaet et raaddent $Æ g$, og dets Indhold løb ned ad ham. Han kom saa tilbage og skulde have sit Halsbind vasket. Det var Brunsvigere. Om vi havde Indkvartering her ude paa Skeldemark, det husker jeg ikke bestemt, dog forekommer det mig, at der laa nogle Oldenborgere her. Der laa ogsaa Hannoveranere, Sachsere og Waldeckere i Byen. - Da Dybbøl Mølle blev nedskudt, var jeg med oppe i Marken at se paa Branden. - Jeg havde som lille Dreng faaet en Brokskade, eller maaske jeg var født dermed. Blandt den tyske Indkvartering, som laa i Skelde, var der en Læge hos Gaardejer Jakob Jakobsen (Thomsen), den Gaard, som Andr. Iversen nu har. Jeg var med min Fader oppe hos ham, og han forskaffede mig et Brokbaand. Jeg kunde imidlertid ikke taale at gaa med det, da det gnavede $\mathrm{Hul}$ paa Kroppen, saa det maatte kasseres. Jeg blev derved saa ængstelig for at bære Brokbaand, at jeg troede senere, at jeg kunde ikke klare mit Arbejde, naar jeg skulde bære et saadant, og jeg lod derfor være med at anskaffe mig et saadant, indtil jeg var 28 Aar. Men efter den Tid blev jeg rigtig nok meget stærkere til at tage fat. ...

I Krigsaarene, naar Oprørerne havde Herredømmet, og der laa tysk Indkvartering her, maatte enhver Mand, som ville forlade Byen, forsyne sig med et Pas fra vedkommende Myndighed til at legitimere sig med, da man var bange for Spioneri. Min Fader var en Dag mistænkt for saadant fra Vandvejen af, hvilket dog var ugrundet. Alle Husets Folk var i denne Anledning i Forhør hos Herredsfogden i Broager. Selv jeg, som kun var ca. 7 Aar gammel, var stævnet; men Herredsfogden gav dog Afkald paa at forhøre mig. Følgen blev imidlertid, at der kom nogle Gendarmer i Indkvartering hos os og i Nabolaget.

I min Skoletid anvendtes den saakaldte sindbyrdes Undervisning", som bestod i, at de store Børn skiftedes til at undervise de smaa. De, der saaledes hjalp ved Undervisningen, kaldtes "Bihjælpere«. Der havdes til dette Brug bl.a. Tabeller til at lære de smaa Børn at læse paa. Efter min Konfirmation søgte Præsterne Karstensen (Provst) og Schleppegrell at faa Roskilde Konvents Salmebog indført i Sognet, men Kirkeværgerne, paavirket af Stemningen i 
Sognet, modsatte sig det, fordi, som det hed sig, det var saa stor en Bekostning at paalægge Menigheden. Man kan deraf slutte, at der har ikke været nogen Forstaaelse af, hvad god Salmesang har at betyde, da "Evangelisk-Kristelig Salmebog « jo var en daarlig Salmebog, som blev indført i den rationalistiske Tid, hvorimod "Roskilde Konvents Salmebog" var meget bedre. I Skolerne, hvor Provsterne og de højere Skolemyndigheder kunde gjøre det, blev den sidste indført. I Kirken blev den gamle Salmebog først mange Aar efter (1889) afløst af en bedre, nemlig »Evangelisk-luthersk Psalmebog for de dansktalende Menigheder i Slesvig«.

I Fyrrerne havde vi en Andenpræst, som hed Wollesen' og var fra Sottrup. Han var en meget dygtig Prædikant, og der gik mange Mennesker i Kirke, naar han prædikede. I denne Tid skulde Konfirmanderne Vinteren igjennem skrive Prædikenerne op. Der ligger endnu en Bog med opskrevne Prædikener af min Stedmoder fra den Tid. Hun holdt meget af ham. Mange, nu for det meste afdøde Folk, har rost ham i høje Toner, og dog har jeg en Mistanke om, at han har været en stærk Rationalist. Han skal have sagt en Gang i et

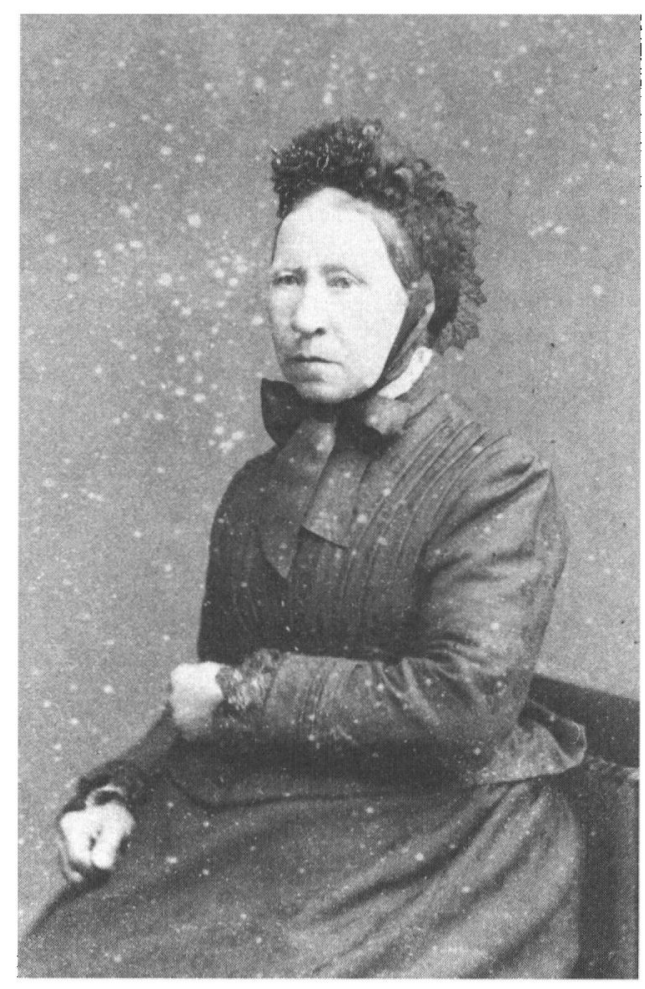

Der findes ingen billeder af Andreas Andresens mor Sophia Maria Andresen, f. Tychsen (1820-50). Derimod er der bevaret et portrat af stedmoderen Anna Maria Andresen (1829-93), der var en saster til Sophia Maria. Fot. af Fr.Chr.Lerche, Broager, i privateje. 
Selskab hos daværende Gaardejer Chr. Tychsen i Skodsbøl, at naar vi var døde, saa var alting forbi. Han førte ogsaa et usædeligt Levnet, hvilket Folk nu ikke kunde lide, og han havde uægte Børn. Derhos var han tillige en ægte "Slesvig-Holstener«, hvorfor han ogsaa kom herfra i eller ved Krigens Slutning. At han trods sine Vildfarelser har kunnet rive Folk med sig i Kirken, maa uden Tvivl have havt sin Grund $i$, at han har havt stor Styrke $i$ at prædike Moral. Hans præstelige Virksomhed har efter mit Skjøn heller ikke efterladt sig noget kristeligt Spor. Der var rigtignok paa den Tid og senere en lille Kreds af saakaldte "Hellige« her i Sognet, men jeg tror ikke, de havde noget med Wollesen at bestille ud over det, at de gik hen at høre hans Prædikener.

Samtidig med ham var Provst Stephensen ${ }^{10}$ Præst her. I det hele taget var der godt Kirkebesøg i min Skoletid, og en Del Aar senere, men at det ikke altsammen var ægte Gudsfrygt, fremgaar af, at enkelte Karle, som var med at kjøre til Kirke, ved Lejlighed nok kunde faa sig et Slag Kort under Gudstjenesten paa det saakaldte "gamle Loft" i det nordre Kapel, hvor der var et temmeligt højt Forværk, saa de kunde gjøre det saa temmelig i Skjul. Trods saadanne Udskejelser, som dog ogsaa langt fra billigedes af Menigheden, maa der sikkert have været stærkere religiøs Trang i Sognet end nu om Stunder, da Kirken næsten staar tom undtagen paa de kirkelige Festdage og i »Altergangstiden« Foraar og Efteraar. Det hørte efter min Opfattelse ogsaa med til god Skik og Tone at gaa til Kirke om Søndagen, og dette holdt sig ogsaa for en Del, indtil der i 1889 indførtes tysk Prædiken en Søndag i hver Maaned. Fra denne Tid omtrent er det, at Kirkebesøget er taget saa stærkt af, skjønt Forargelsen derover just ikke har givet sig til Kjende paa anden Maade. Det maa vel siges, at Prasternes (Provst Reuters og Pastor Schumachers) ${ }^{11}$ offentlige Fremtræeden som Tyskere har medvirket meget dertil.

Angaaende Befolkningens nationale Standpunkt før 1848 kan jeg selvfølgelig ikke meddele noget af egen Erfaring, men derimod nok nogle spredte Træk efter mundtlig Overlevering: Min Fader, der dog senere var saa god en dansk Mand som nogen, har gjort enkelte skriftlige Optegnelser i Fyrrerne paa Tysk, og det samme ved jeg om enkelte andre, endog senere fremragende danske Mænd, f.Eks. gamle Chr. Petersen i Dynt og Chr. Hanssen, Nørremølle, hvilken sidste endog har skrevet tyske Smaadigte. Man var inde paa, at vi var ikke egentlige Danske, men »Slesvigere«, uden Tvivl en opagiteret Forestilling, som straks forsvandt, da "Aanden fra 1848 « kom til at gjøre sig gældende ogsaa her. Medens der saaledes tilsyneladende nær op til 1848 ikke var megen Forskjel mellem Folk i national Henseende, skete der en Splittelse i Krigens Tid, og de saakaldte "Hjemmetyskere" kom frem. Her i Byen var de mest fremtrædende: Gaardejer Jens Peter Clausen, nuværende Jens Peter Clausens Farfader, Broderen Claus Clausen paa Skeldegaard, Kaadner Rasmus Smidt, 
og Hans Tychsen, nuværende Peter Tychsens Farbroder paa Skeldemark (Dyntmark). De var til Dels paavirkede af gamle Matzen paa Krammark, som igjen stod i Forbindelse med nogle tysksindede Teglværksejere ved Egernsund, Møller Desler, Dyntmølle, Møller Clausen, Broagermølle, Ehnstedt, Broager, Glarmester Dideriksen, Doktor Schirmhoff og flere i Broager, Skovridder Grotrian i Dynt, o.fl.

Min Morbroder, Jakob Tychsen, som havde tjent hos Ehnstedt paa Brændevinsbrænderiet i Brunsnæs, og paa Angel, blev ogsaa smittet af Tyskeriet, og senere adskillige flere. Før Krigen blev der undertiden sunget tyske Viser jævnsides med danske i Selskaber. Det var for det meste Drikkeviser og Kjærlighedsviser, der blev sungne. Min Fader, som sang meget i Selskaber, havde gjerne en Sangbog med, som indeholdt baade danske og tyske Sange. Det var dog kun enkelte tyske Sange, der blev sunget; men noget Anstød vakte dette ikke den Gang. Efter Krigen blev dette mere sjældent, men det var dog ikke helt udelukket. De danske Fædrelands- og Krigssange kom nu paa Mode.

Efter Krigen forholdt Slesvig-Holstenerne, som gerne blev kaldt »Hjemmetyskerne«, sig tilsyneladende meget rolige, og der toges intet Hensyn til dem. Der blev ganske anderledes Liv i Befolkningen, og man følte sig meget mere som danske. Min Fader fik en ny dansk Sangbog med Noder til, og da han i sin Ungdom havde lært at spille paa Violin, saa kunde han indøve sig i nogle af Melodierne, skjønt det faldt ham lidt svært, da han var kommen for meget fra det. Han havde ellers spillet en Del til Dans i sine unge Dage, dels i Kroen og dels omkring ved Bønderne, hvor der undertiden ogsaa holdtes Dans. Der ligger endnu et Regnskab af ham over, hvad det har kostet ham at lære, og hvor meget han har taget ind ved at spille. Det opviser kun et lille Overskud.

I denne Forbindelse kan jeg meddele, at jeg tilligemed min Søster Marie Sophie fik Del i et Dansekursus i Broager i vor Skoletid tilligemed nogle flere Børn her fra Byen og den øvrige Del af Sognet. Jeg var ellers ikke meget for det, kan jeg huske, det var jo noget nyt; navnlig var jeg meget kjed af, at da vi skulle have Sko, og ikke Støvler, saa fik jeg et Par, der var noget grove, og Danselæreren, Hans Andresen fra Nordborg, sagde en Dag, at det var ikke hans Mening, at det skulle være "Plovsko«, men derimod "Dansesko«, og derved troede jeg jo, han hentydede til mine. Jeg beholdt dog alligevel mine »Plovsko«. Hans Andresen var en streng Lærer, som ikke var til at spøge med, naar det ikke gik efter hans Hoved. -

Af nyt der kom op noget senere, efter min Konfirmation, kan jeg nævne Fotografiet. En Fotograf fra Graasten rejste rundt og "tog af «, og da han ogsaa kom her til Byen, maatte jeg og mine Søskende "for Brædtet«. Jeg kan nok huske, at det var ikke med min bedste Vilie, jeg gik med til dette; jeg 
syntes, det var noget sært noget, som ikke alle gik med til. Vi blev fotograferede herhjemme paa Gaardspladsen, og Billedet blev meget godt. Det var det saakaldte Daguerreotypi (paa Glasplader). I min Skoletid holdt den første Symaskine sit Indtog i Skelde, idet Skræddermester Chr. Philipsen, som boede lige over for Skolen, anskaffede sig en saadan. -

Det var i min Barndom meget sjældent, at Børn kom videre end højst til Sønderborg. Jeg var derfor meget glad ved, at jeg en Søndag kom med mine Forældre til Tandselle paa Als i Besøg hos Tøge Gregersen, som en kort Tid havde et lille Landsted der. Det var i Sommertiden, og jeg kan huske, hvor interessant det navnlig forekom mig med de mange Jordbær, som voksede paa Digerne ved Landevejen paa Als. En Gang (det var efter min Faders Optegnelser d. 3.4. Septbr. 1854) var jeg med mine Forældre kjørende til Flensborg. Det var den Gang, Jernbanerne var bleven bygget Syd fra indtil Flensborg. Fader fik da Lyst til, at vi skulde prøve at kjøre paa den, og vi kom saa med til en Station, som hed Øster Ørsted og tilbage igjen med det næste Tog. Vi laa over om Natten i Flensborg og kjørte hjem næste Dag. Dette var, mindes jeg, noget af en Begivenhed i de Dage, og det var noget at fortælle om til mine Skolekammerater. Dampskibsforbindelse med Flensborg var der ikke Tale om den Gang; derfor maatte der kjøres udenom. Jeg var ogsaa en Vinterdag, da der var Havis, kjørende med mine Forældre til Lyksborg paa Kane. Vi kjørte ud fra den gamle Færgebro over til Holdnæs og derfra over Land til Lyksborg. Det var forresten noget voveligt, da der ingen havde kjørt paa Isen før, men Fader var ikke bange, og det gik ogsaa godt. Fader havde en fjærn Slægtning, Tømrer Carl Johan Thomsen i Lyksborg, som vi besøgte. En Søn af ham, som hed Fritz, kom senere til at tjene hos os, men han blev om kort Tid syg, kom hjem og døde. En anden Søn, som hed Hans, kom til Søes. Efter min Faders Død har jeg slet ikke hørt noget til Familien.

\section{Konfirmation}

Jeg blev konfirmeret d. 28. Marts 1858 og var saaledes 16 Aar gammel, hvilket ikke var helt ualmindeligt den Gang, skjønt jeg godt kunde være kommen med Aaret før. Mine Medkonfirmander af Drengene fra Skelde Skole var: Andreas Andersen fra Skelde Vandstedbæk, død som Mejeri- og Gaardejer paa Langeland, Claus Peter Wolff fra Gammelgab, Lorens P. Godt fra Skodsbølmark, som tjente hos Thomas Thomsen i Overballe, Andreas Andersen fra Midtballe, senere Gaardejer i Smøl, Peter Nissen fra Skeldegaardskobbel, nu Gaardejer ved Faaborg, gift med Pastor Aabys Datter fra Lyø, Jørgen Peter Petersen fra Skelde-Dyntmark, nu Træskomager i Gammelgab, Christian 
Thomsen fra Skeldegaardskobbel, nu Landmand i Skovbøl og Peter Heinrich Petersen, i Tjeneste paa Skeldegaard, nu bosiddende i Smøl.

Pastor Schleppegrell, som konfirmerede os, var vel noget streng, men vi holdt alligevel af ham. Han havde været med i 3 Aars Krigen som Løjtenant og var en Brodersøn af den navnkundige General Schleppegrell, som faldt ved Isted. Der var ogsaa noget militærisk i Præstens Holdning og Optræden. Hans Prædikener var korte, men gode, skjønt han var noget barsk i sin Udtale. Slutningen kom næsten altid, førend Folk ventede det. Han var en godgjørende Mand, og han gav bort, saalænge han havde noget at give af, saa hans Familie ofte havde det smaat. Forstepræsten i Sognet den gang var Provst Karstensen, en Gaardmandssøn fra Kjær paa Als. Han holdt i Modsætning til Schleppegrell temmelig lange Prædikener og var ofte meget bevæget derved. Der var god Kirkegang paa den Tid. Begge Præster var udpræget dansksindede, saa da Krigen brød ud i 1864, fandt Schleppegrell sig foranlediget til at flygte til Kjøbenhavn kort efter Tyskernes Ankomst hertil, medens Karstensen blev afsat kort efter; han fik dog Børnene konfirmeret først, men længe før den sædvanlige Tid. Min Broder Tøge blev konfirmeret hos ham. Pastor Schleppegrell var en af de faa, som frygtede for, at Broagerland vilde blive besat af Fjenden, for at de fra Dyntmark kunde beskyde Dybbølskanserne, og dette slog jo desværre til.

Efter min Konfirmation blev jeg hjemme i 3 Aar og skulde altsaa blive ved Landvæsenet, skjønt jeg nok kan sige, at det ikke rigtig huede mig altid. Dertil bidrog det en hel Del, at Førstekarlen, vi havde, Johan Gerhard Hansen, undertiden giorde mig forknyt, fordi han, som selv var en dygtig Karl og indbildte sig at være endnu dygtigere, end han var, undertiden lod sig forlyde med, at jeg aldrig fik lært at pløje og kjøre ordentligt. Han bidrog nu heller ikke selv meget dertil, for han viste mig ikke til rette dermed, og naar jeg bad ham derom, saa kunde han undertiden svare mig, at det kunde min Fader jo lære mig. Min Fader, som sikkert ingen Anelse havde om saadant, da jeg tav stille dermed, lod det gaa, som det kunde. Vi havde den Gang faaet den første Svingplov, som Johan altid pløjede med og gjorde det godt, men at jeg kunde faa lært at pløje med den, kunde der efter hans Udtalelser ikke være Tale om. Vi fik saa nok en Svingplov, som var lavet paa Angel, men den gik ikke godt, og saa maatte jeg bruge den gamle Hjulplov, og det blev ikke altid saa rigtigt paa Grund af den vanskelige Stillen med Trækilerne og sligt.

Jeg havde derfor, sandt at sige, ikke store Tanker om mig selv og min Fremtid som Bondekarl, og det var slet ikke med de største Forventninger, jeg tog paa det, da Fader begyndte at tale om, at jeg skulde ud i Verden at se mig om og lære noget andre Steder. Han talte først om at faa mig paa Rødding Højskole, men dette frabad jeg mig, da jeg syntes, det ikke var noget for mig, 
og jeg generede mig ved det. Saa blev dette opgivet, og Fader forhørte sig om en Plads til mig paa Gaarden "Koldmos« ved Rinkenæs, men den var ikke at faa, og glad var jeg. Derefter talte Fader om at faa Plads til mig hos Knudsen paa Lysholm paa Als; men saa ytrede jeg mig om hellere at komme til at tjene hos en bonde, hvilket jeg syntes passede bedre for mig. Fader fik saa talt med sin Fætter, Mathias Juhler i Sønderborg, om Sagen, og han vidste, at der var en dygtig Gaardmand i Egen paa Als, nemlig Jørgen Frederiksen, og det blev aftalt, at han, Math. Juhler, skulde kjøre med os derover.

\section{Tjenestekarl på Als}

Det var i Vinteren 1861. Vi kjørte i Kane derover og blev godt modtagne, men J. Frederiksen havde ikke netop Brug for mig dette Aar, hvorimod han mente, at hans Fader, Hans Jørgen Frederiksen, som havde en Gaard i samme By, kunde maaske have mig. Vi gik saa derhen, og det blev aftalt, at jeg kunde komme dertil. Jeg fik et godt Indtryk af disse jæune Folk og var ret glad ved denne Afgjørelse, og den 1. Maj 1861 tog jeg Afsked fra Hjemmet for første Gang. Fader kjørte mig til min ny Plads. Her varede det ikke længe, førend jeg fik mere Mod paa og bedre Forstaaelse af min Gjerning, saa det kom til at gaa med Liv og Lyst. Vi var 3 Karle, nemlig Førstekarlen, Laurids Jørgensen, som var Mandens Søstersøn, en ældre, dygtig og meget forstandig Karl; jeg var Andenkarl, og først var Mandens Sønnesøn og senere Peter Andersen fra Elstrup Trediekarl.

Der herskede stor Orden ved Arbejdet, og saa blev der talt og forhandlet baade om det ene og det andet, hvorledes dette eller hint bedst skulde giøres, og dette var noget, som jeg ret syntes om. Med Pløjningen, som jo navnlig var min svage Side, gik det snart bedre. Jeg kunde faa hvilken af de 2 Svingplove og hvilket af de 2 Spand Heste, vi havde, at bruge, som jeg bedst syntes om, og da de gik godt, og det ikke manglede paa Vejledning, varede det ikke længe, førend jeg fik Tillid til mig selv og blev, som gamle Frederiksen sagde, »Herre over Ploven«. Laurids Jørgensen var en dygtig Pløjemand, og Ploven gik som sagt meget godt. Han havde faaet Præmie ved en eller to Præmiepløjninger, navnlig en Gang 2den Præmie ved Graasten. Jørgen Frederiksen havde ligeledes faaet Præmie for Pløjning, Laurids var derhos en dygtig Husflidsmand, navnlig til Huggehusarbejde, og dette kom mig ret tilpas, da jeg hjemme under Faders Vejledning havde øvet mig noget deri og havde stor Lyst dertil.

Den Gang stod det endnu ret godt til mange Steder med den mandlige Husflid, som nu til Dags er »lagt paa Hylden« de fleste Steder. I Fritiden, 
9 shttm Dimblis da Ondveas. Ondrejen trow

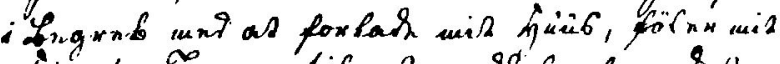

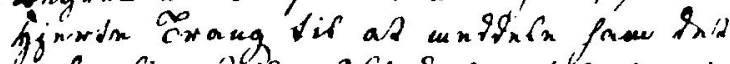

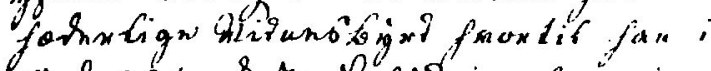

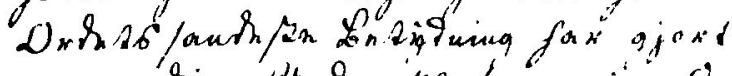

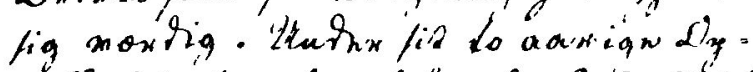

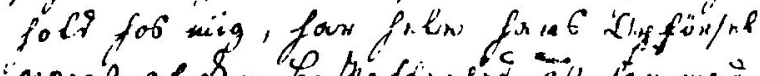

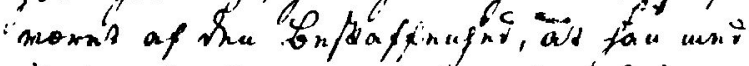

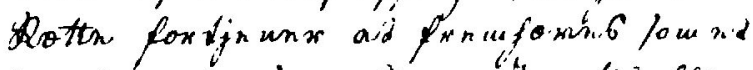

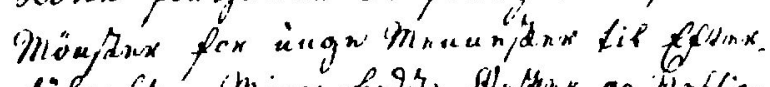

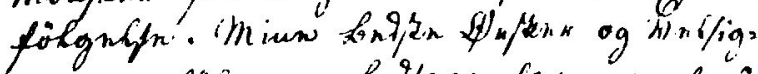

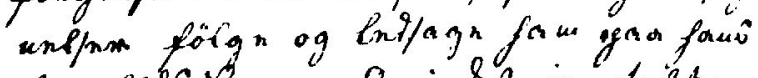

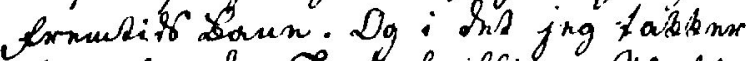

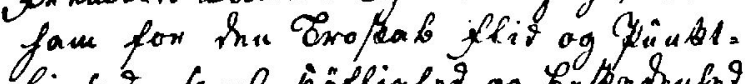

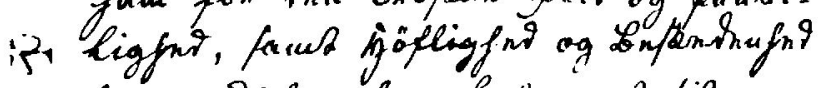
fmox munt four farr bnsingund fid

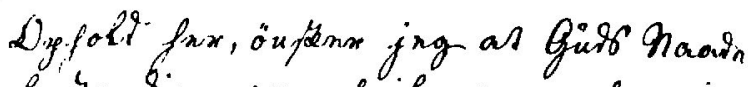
bryautig unaw frill onnst face : aftn fawi fornoagnuhr, og uassulig oulthx jog, wave fau flugang/nkn

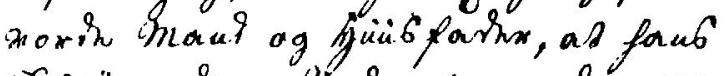

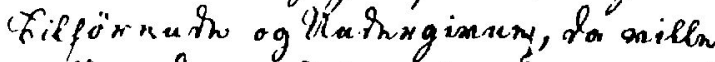

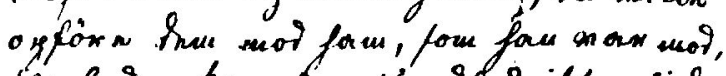

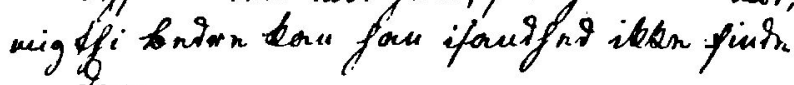
onsu.

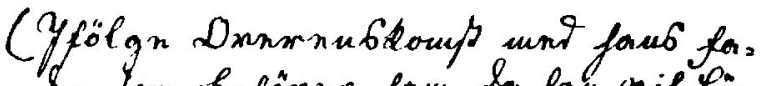

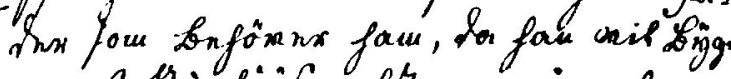

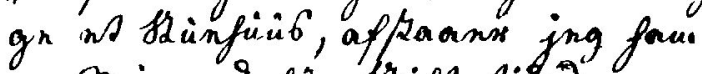

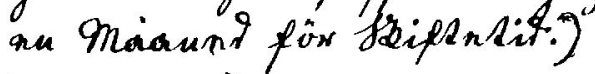

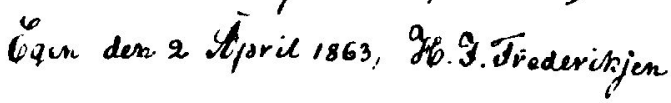

Udsnit fra Andreas Andresens skudsmålsbog. Som det ses af gårdejer H.J. Frederiksens vidnesbyrd, var Andreas Andresen en afholdt tjenestekarl pả gården i Egen 1861-63. I privateje. 
navnlig om Søndagen, var vi derfor gode at finde i Huggehuset. En der i Byen boende Skrædder, som ogsaa var dygtig i Træarbejde, kom ofte hen til os og vi til ham, og saa blev der talt om, hvad der skulde laves og om Fremgangsmaaden dermed. Desuden var der flere Karle der i Byen, som var dygtige til Husflid, navnlig Brødrene Hans Peter og Jørgen Bonde. Jeg fik lavet mig noget Huggehus-Værktøj; men Høvlene turde jeg ikke give mig i Lag med, men lod en Snedkersvend lave mig nogle; da jeg imidlertid manglede en til, saa tog jeg fat paa at lave en selv, og den blev god. Da jeg saaledes havde faaet noget Værktøj, saa skulde jeg da ogsaa have et Skab til at gjemme det i. Træet dertil gav min Husbond mig, og det gjorde han saa gjærne, sagde han, da han satte stor Pris paa, at vi benyttede vor Fritid paa denne Maade, for saa vidste han, hvor han kunde finde os.

Tærskningen, som den Gang næsten alle Steder skete med Plejl, besørgedes for det meste af Peter Andersen og mig, medens Laurids tog Tag af, gjorde Kjørslerne og andet Arbejde. Den sidste Vinter jeg var der, tog Peter Andersen og jeg Akkord med at tærske hele Avlen. Vi skulde være færdige til en bestemt Tid, men de Dage, vi skulde med til Mark- og Skovarbejde m.m. blev regnet os til Gode. Vi fik ved denne Akkord 3 Uger fri, som vi saa skulde have Dagløn for; men til min store Beklagelse fandt min Fader paa, om det ikke kunde lade sig gjøre, at jeg kom hjem de 3 Uger før Maj, da han havde god Brug for min Hjælp paa Grund af, at vi skulde bygge et nyt Stuehus, og jeg kom altsaa hjem først i April 1863 efter næppe 2 Aars Ophold der. Jeg vilde gjærne være blevet paa Als noget længere, og $\mathrm{H}$. Frederiksen havde tidligere talt med Jørgen Smedemand, Stolbrolykke om Plads for mig hos ham, da jeg, ogsaa efter hans Mening, kunde have godt af at komme et andet Sted hen; men det blev jo saa ikke til noget paa Grund af Byggeriet hjemme.

Egen By kom til at staa for mig $i$ en egen Glands, hvortil det jo ogsaa bidrog, at jeg der fandt min tilkommende Livsledsagerinde ${ }^{12}$. Vor Forbindelse blev i al Hemmelighed indledet i den Tid, jeg var der; men paa Grund af vor unge Alder og af mine Forældres Uvillie derimod blev vi ikke forlovede før $\mathrm{i}$ Januar Maaned 1864. Jeg havde været i Besøg i Egen i Julen 1863 og blev syg kort efter min Hjemkomst derfra. Det begyndte med en Forstoppelse, men slog sig til Hovedet, saa jeg var en Tid næsten fra Samlingen. Lægen, gamle Dr. Schirmhof i Broager, forskede hos mine Forældre efter, om der ikke skulde være en Kjærlighedshistorie til Grund for Sygdommen, og da de befrygtede det samme, saa drog Fader til Egen og fik afgjort, at min Kjæreste skulde komme her over, saa vi kunde blive forlovede. Dette skete saa kort efter, idet Laurids Jørgensen, som var min Fortrolige, kom kjørende her over med hende. Jeg bedredes derefter ret godt, men havde dog Men af Sygdommen $i$ lang Tid paa Grund af Nervesvækkelse. Jeg var dog med at gjøre Krigskjørsler i Løbet af Foraaret, og efterhaanden kom jeg mig godt igjen. 


\section{Landbruget i tiden mellem krigene}

Den 1. Maj 1863 flyttede Johan Gerhard Hansen fra os efter 7 Aars Tjeneste, og jeg blev Forkarl, efter som omtalt at være kommen hjem 3 Uger i Forvejen. Vi havde en travl Sommer paa Grund af Byggeriet, ved hvilket vi selv gjorde Haandlangerarbejde. Vi havde, foruden en Andenkarl, dog en Daglejer til Hjælp. Martin Thumann fra Skelde var Mur- og Tømmermester, og Frederik Klint sammesteds havde Snedkerarbejdet, altsammen for Dagløn. Der stod et gammelt Aftægt, til Dels paa den Plads, hvor Stuehuset skulde bygges; dette skulde altsaa først nedbrydes, og i Efteraaret blev der meget lavet om i det gamle Stuehus, hvoraf der bl.a. ogsaa blev nedbrudt 2 Fag ved den østre Ende. Kjærneværket tilligemed Kværnen og Indretningen til Hakkelseskæring, som for 8-9 Aar siden var blevet anbragt i det gamle Aftægt, blev nu ogsaa anbragt i det gamle Stuehus. - Stuehuset har efter min Faders Optegnelser kostet 4.160 Mark at opføre, deri indbefattet Kosten til Haandværkerne samt Løn til en Haandlanger, men ikke vort eget Arbejde. Det maa bemærkes, at hvad der kunde bruges af Materialet af det nedbrudte Aftægtshus, er ikke sat til Pris. Daglønnen til Haandværkerne var 3 Mark Rigsmønt (1 M. 12/2 Pf.), og Murstenene, som for største Delen kjøbtes hos Jacob Tychsen, Nybølnor, kostede 5 Rigsbankdaler (11 M. 25 Pf.) pr. Tusind.

I Sommeren 1863 havde vi sidste Gang Raps, det var i Hvenmose ved den vestre Side. Rapsen gav i sin Tid et godt Udbytte, og mange Gaardmænd dyrkede den i min Barndom og første Ungdomstid. Af min Faders Regnskaber sees, at han havde dyrket Raps fra 1839, da han overtog Gaarden, til 1846 (incl.). Derefter har han holdt op dermed indtil 1857-63. I 1839 kostede den 17 Mark pr. Tønde, i 1859=20//4 Mark, i $1863=181 / 8$ Mark - alt beregnet til nuværende tysk Mønt. Der staar i Regnskaberne ikke noget om, hvor stort Areal, der hvert Aar har været besaaet, hvorimod nok hvor mange Tonder, der er avlet. Udsæden har i Reglen været 1 Skjæppe aarlig. Jeg synes, at f.Eks. i 1863 kunde det være omtrent det halve Indtægt. Dette Aar er der avlet 24 Tønder, men det har nok været et af de bedste Aar, og hvad Prisen angaar, vistnok det allerbedste. Rapsen saaedes altid i Brakjord (Helbrak), og med Staldgjødning. Efter Rapsen fulgte Vintersæd, som nok kunde blive god uden Gjødning. Tærskningen af Rapsen foregik her paa Egnen i Loerne, hvorimod den mange andre Steder skete ude i Marken paa store Sejl. Saatiden var i den første Del af Juli Maaned, nogle Dage før Rapsen var moden og skulde skjæres. Der skulde derfor gjemmes af det foregaaende Aars Avl til Sæd.

Af min Faders Optegnelser sees, at han første Gang har saaet Roer (Runkelroer og Turnips) i 1854. De saaedes den 9. Maj. Det var dog kun i mange Aar Smaastykker, og det var først i 70erne, at der begyndtes med at dyrke større 

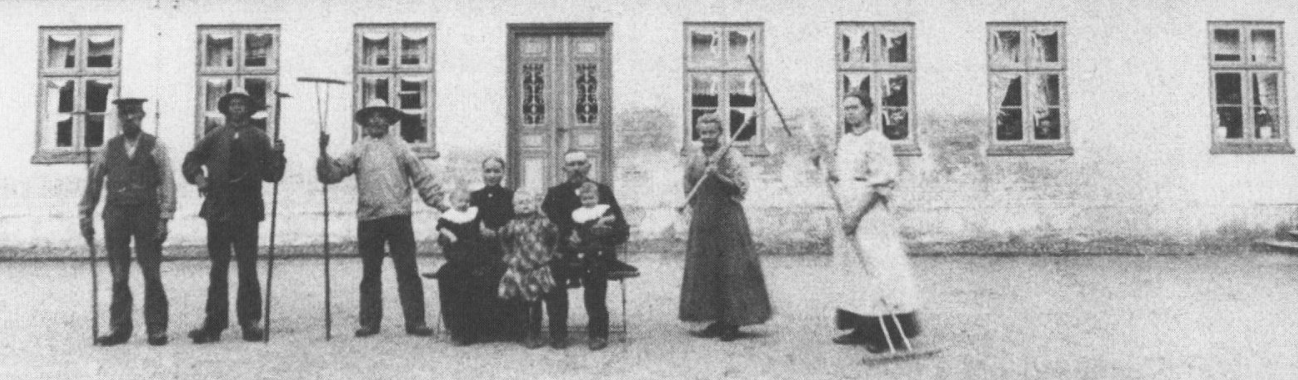

I 1863 blev stuehuset på Rojhus nyopfort, mens det gamle stuehus blev gjort til avlsbygning. På billedet fra ca. 1908-09 ses Andreas Andresen og hustruen Ane Margrethe med tre af bornebornene og tjenestefolkene på gårdspladsen. Faget langst til hojre på stuehuset og indgangspartiet sammesteds blev opfort i 1903 som aftagtsholig for Andreas Andresen. Fot, i privateje.

Stykker med Roer. I Fyrrerne og langt op i 50erne dreves Kartoffeldyrkningen stærkt her paa Egnen og gav i mange Aar et godt Udbytte, især for Kartoffelsygdommen optraadte midt i Fyrrerne. Mange af dem blev opfodrede paa Malkekøerne, men en Del solgtes, undertiden til ret gode Priser. Kornet solgtes for det meste altsammen undtagen Havren til Hestene, Rug til Brød, Byg til Mel og Gryn og Boghvede til Gryn og naturligvis Saasæden. Af min Faders Regnskaber sees, at der fra 1849 er opfodret ca. 18-30 Tønder Korn aarlig, og det var endda ikke saa lidt efter den Tids Forhold. Svin holdtes der ikke stort flere af end til eget Brug, og naar der en Gang imellem i »Slagtetiden« ved Novembertide kunde sælges et Svin eller to, saa var det altid i slagtet Tilstand. Mange Steder gaves der slet intet Korn til Malkekøerne. Det var derfor heller ingen Sjældenhed saadanne Steder, især i Foraaret, naar Malkekøerne havde kælvet og gav Mælk, at enkelte af dem maatte have Hjælp for at 
kunne rejse sig. Først naar de kom ud og fik noget af det unge kraftige Græs, kom de til kræfter og gav nogen Mælk af Betydning.

Af min Faders Regnskaber sees det dog, at Smørproduktionen har havt nogen Betydning her paa Gaarden. Smørudbyttet har været følgende:

I 1839

1840-41 Kjærnet 84 L.pund,

1841-42 Kjarnet ca 100 L.pund

1842-43 Kjærnet 1260 Pund,

1843-44 Kjarnet 1078 Pund,

1844-45 Kjarnet 938 Pund,

1845-46 Kjærnet 938 Pund,

1847-48 Kjærnet 1386 Pund,

1848-49 Kjarnet 1476 Pund,

1849-50 Kjærnet 1442 Pund,

1850-51 Kjærnet 1249 Pund,

1851-52 *Kjærnet 1737 Pund,

1852-53 Kjærnet 1974 Pund,

1853-54 Kjærnet 1781 Pund,

1854-55 Kjarnet 1599 Pund,

1855-56 Kjærnet 1610 Pund,

1856-57 Kjarnet 1491 Pund,

1857-58 Kjarnet 1104 Pund,

1858-59 Kjærnet 1148 Pund,

1859-60 Kjærnet 1211 Pund,

1860-61 Kjarnet 1464 Pund,

1861-62 Kjarnet 1574 Pund,

1862-63 Kjarnet 1528 Pund,

1863-64 Kjarnet 1375 Pund,

1864-65 Kjarnet 1381 Pund,

1865-66 Kjarnet 1290 Pund,

1866-67 Kjærnet 1196 Pund,

1867-68 Kjærnet 1676 Pund,

1868-69 Kjarnet 1232 Pund,
Solgt 391/4 Lispund á 14 Pund for 237 Mark

solgt 51 $1 / 4$ L.pund for 369 Mark

solgt $59 \frac{1}{2}$ L.pund for 404 Mark

solgt 707 Pund for 364 Mark

solgt 595 Pund for 292 Mark

solgt 455 Pund for 237 Mark

solgt 679 Pund for 336 Mark

solgt 985 Pund for 666 Mark

solgt 1224 Pund for 637 Mark

solgt 1162 Pund for 573 Mark

solgt 1058 Pund for 525 Mark

solgt 1491 Pund

solgt 1582 Pund

solgt 1435 Pund

solgt 1284 Pund

solgt 1264 Pund

solgt 1162 Pund

solgt 805 Pund

solgt 833 Pund

solgt 963 Pund

solgt 1107 Pund

solgt 1234 Pund

solgt 1080 Pund

solgt 986 Pund

solgt 1041 Pund

solgt 986 Pund

solgt 892 Pund

solgt 1334 Pund

solgt 973 Pund

* Da der fra dette Regnskabsaar 1851-52 aarlig er medregnet Indtagt af Kalve og Skind til Indtagten af Smor, saa kan denne sidste ikke kontrolleres, hvorfor den herefter udelades.

I 1839 har Smørret kostet ca. 43 Pf. pr. Pund, i $1840=51 \frac{1}{2}$, i $1841-46$ omtrent samme Pris.

Da der efter den første Mærgling ikke sørgedes tilstrækkeligt for at tilføre Jorden Gjødning nok, maatte den Tid komme, da den blev mere eller mindre udpint, og da Fader en Tid lang, lige som saa mange andre, brugte et temmelig udpinende Sædskifte, saa tog Frugtbarheden betydeligt af, hvilket især mærkedes i de 3 tørre Somre 1857-58-59. Dertil kom den meget følelige Skade, som Oldenborrelarverne tilføjede os, særlig i Sommeren 1857. Deres Hærgning var især følelig paa den østre Del af Skeldemark og i Skeldegaardskobbel. Vi opsamlede Larver efter Ploven, og det var helt storartet, saa mange der var, 
men det forslog dog ikke til at udrydde dem. Vi fik da også flere OldenborrePerioder (hvert 4de Aar) efter den Tid, hvori de hærgede mere eller mindre slemt paa forskjellige Strøg her i Omegnen, og da værst naar de paagjældende Somre var tørre. Men i 1871 , da det var Oldenborre-Aar, blev det besluttet i Kommunen, at der skulde indsamles Oldenborrer i Flyvetiden, og de skulde betales med 5 Pf. pr. Pund af Kommunen efter Hektar-Areal. Der var en stor Mængde denne Sommer, og de fleste Beboere gjorde sig Umage med at samle. Der blev samlet ca. 16.000 Pund i Skelde Kommune. Dette hjalp ikke saa lidt, og da der fortsattes dermed i flere Perioder, mærkedes det, at de svandt stærkt. Ved Siden deraf tog Fuglene rigtig nok ogsaa til i Antal og hjalp til at udrydde disse skadelige Insekter, saa nu er de næsten helt forsvundne her i Egnen.

\section{Krigen 1864}

Den 15. November 1863 døde Kong Frederik den 7. paa Lyksborg Slot, og nogle Dage derefter førtes hans Lig her forbi pr. Dampskib. I denne Anledning havde Fader faaet Sangforeningen "Harmonien«s Fane herover for at flage paa halv Stang omme paa vor Nabo, Hans Christensens, Kløft, naar det blev om Dagen, og et Blus blev forberedt til at afbrændes, naar det blev om Aftenen. Det sidste blev Tilfældet.

Det voldte stor Uro i Befolkningen, da Krigen udbrod i Februar 1864, og især da det rygtedes, at den danske Hær var paa Tilbagetog fra Dannevirke. Tilbagetoget var overordentligt anstrængende for Armeen, særlig ogsaa paa Grund af haard Vinter med Sne og glat Føre. Fader var, den Dag Armeen hovedsagelig ankom til Dybbøl, kjørende til Gaarden Stenbæk ved Vemmingbund med et Anker varmt Eggeøl til Soldaterne, hvilket derfra blev bragt dem til Vederkvægelse, og saaledes hjalp en og anden til at lindre Nøden blandt dem. Der blev udskrevet Leverancer af Hø og Halm til Dybbøl Skandser lige før Armeens Ankomst m.m. Vi var derovre med et Læs, men den dag var jeg ikke med. Derimod var jeg til Dybbøl at hente et Læs Møbler hos Thomas Asmussen, som blev staaende hos os i lang Tid. Beboerne i Dybbøl og nærmeste Omegn maatte jo rykke ud. Jeg saa den Dag noget af Elendigheden ved Tilbagetoget, medens jeg kjørte over Chausseen ved Hvilhøj.

Det varede ikke længe, før de prøjsiske Tropper kom; men det varede dog noget, inden der kom nogen herover. Den 3. Marts fik vi den første Indkvartering, nemlig 37 Mand af det 35te Regiment (Brandenborgere). Folk var helt ude af sig selv af Bestyrtelse over Begivenhedernes Gang. Man havde ikke ventet, at Danevirke ikke kunde holdes, og man troede, der var Forræderi med i Spillet. Dertil var man ligefrem bange for den fjendtlige Indkvartering 
eller havde stor Uvillie, ja ligefrem Modbydelighed for den. Folk gik og drev, og der blev i mange Dage saa at sige ingen Ting bestilt, undtagen det helt nødvendige. Imidlertid viste det sig, at Soldaterne i Almindelighed var inde paa, at vi havde det saa daarligt under det danske Regimente og sagde, at de var komne for at befri os. Dette vilde vi naturligvis ikke høre Tale om, og vi ønskede dem Pokker i Vold. Egentlig Overlast øvede de dog ikke imod os, men det var alligevel en meget kjedelig Tid med al den Uro og Besvær, den forte med sig. Vi havde ofte 30-40 Mand i Indkvartering, og da det var Vintertid, maatte de ligge inde i Stuehuset. Storstuen og Dagligstuen var fulde af Menige, de fik et godt Lag Klapning ${ }^{13}$ at ligge i. I den saakaldte lille Stue havde vi til en Tid 2 Underofficerer, senere en Feldwebel, saa en Sergent. Af Rytteri havde vi næsten intet. Andre Steder, ogsaa oppe i Byen, havde de langt større Indkvartering.

Den eneste Fortrøstning, vi havde, var den, at Dybbølstillingen nok skulde holde, og vi var somme Tider uenige med en eller anden af Soldaterne derom. De mente jo det modsatte og pralede af deres Baglade-Geværer og deres langtrækkende Kanoner, hvilke jo desværre ogsaa viste sig at være de danske Geværer og Kanoner langt overlegne. Det var den første Krig, hvori dette ny Skyts kom i Anvendelse. Det var en stor Skuffelse for os, da Dybbøl den 18. April faldt, saa det var den almindelige Mening, at der ogsaa derved var Forræderi med i Spillet. Af vor Indkvartering faldt der 1 Mand. Hvor de hoverede efter denne Bedrift! Jeg glemmer aldrig denne Dag med den storartede Kanontorden en lang Tid, indtil den tilsidst afløstes af Geværsalver. Skandserne, som jo i Forvejen var ødelagte, beskødes dels fra Dyntmark og dels fra Avnbjerghøj ved Frydendal, medens Fodfolket rykkede frem ad de i Forvejen paa den søndre Side af Chausseen mellem Frydendal og Skandserne i Zig-Zag opkastede Løbegrave, og da de saa var tilstrækkelig nær inde paa Skandserne til, at der kunde stormes, saa standsedes Kanonskydningen. Klokken var da hen ved 10 om Formiddagen.

Vi haabede hele Tiden under Dybbøls Belejring, at der skulde komme Hjælp ude fra, men denne udeblev jo. Til Trods derfor havde vi sikkert Haab om, at Als skulde nok holde sig; men dette Haab skulde ogsaa briste. I Tiden efter Dybbøl's Fald havde vi ikke saa megen Indkvartering herovre. En stor Mængde Fiskerbaade blev tilvejebragte fra en vid Omkreds og ført til Sottrupskov, hvorfra Overgangen skete til Arnkil paa Als den 29. Juni. Nogle Dage før Overgangen, nemlig den 26., blev der beordret 6 Baade fra Stranden ved Skelde Skov, der hvor Dampskibsbroen nu er, kjørt over til Dybbøl Skandser. Jeg var kjørende med en af dem; de øvrige Karle, der var med, var: Hans Peter Jensen fra Skeldegaardskobbel, Peter Philipsen her fra Skeldemark, Chr. Thomsen, nuvarende Handelsmand ved Korsvejen, Philip Andersen fra 
Vandstedbæk og Peter Paulsen fra Skelde. Vi holdt med Baadene paa Dybbøl Banke til venstre for Landevejen, omtrent der, hvor den danske Skandse Nr. 5 var.

Hestene blev spændt fra og tøjrede i Græsset der omkring, og vi maatte blive der til den 28. om Aftenen, da fik vi Tilladelse til at drage ned med Hestene i Kvarter i Dybbøl By. Men det varede kun til hen imod Midnat, saa blev vi kommanderet op for at kjøre Baadene ned til Vandet. Vi troede først, at det skulde være til Havnen overfor Sønderborg; men det blev dog til Vemmingbund, de skulde; vi kom ikke til at kjøre dem længere end over paa den anden Side af Landevejen, hvorfra Soldaterne saa trak dem ned til Stranden, medens vi blev kommanderede til at lejre os paa samme Plads, hvor vi havde holdt med Baadene. Et Par Gange, medens vi endnu holdt der med Baadene, blev disse trukne frem og tilbage $i$ forskjellige Stillinger, vist nok for at vildlede de Danske paa Als, der sikkert skulde have Indtryk af, at der var fuldt af Baade i Lavningen ved Dybbøl, og at Overgangen skulde foregaa ved Sønderborg. Der blev en Skildvagt ansat hos os og Hestene, efter at vi var placerede paa det omtalte Sted.

Hen imod K1. 2 begyndte man at skyde omme ved Sandbjerg og Sottrupskov, og da det kort efter lysnede lidt, kunde vi begynde at skimte Overfarten i Baade deromme. Nu begyndte man at beskyde Dybbølstillingen ovre fra Bosager- og Kirkebatterierne, og vi blev naturligvis noget ængstelige, da Granaterne slog ned rundt omkring os, enkelte ganske i vor Nærhed. Vi talte med Skildvagten om at lade os drage ned til Dybbøl, men han afslog det og sagde, at han havde Ordre til at skyde, naar nogen af os søgte at undslippe. Da Skydningen blev heftigere, saa vi, at han blev ganske bleg, og kort Tid efter var han forsvunden fra sin Post, uden at nogen af os havde lagt Mærke dertil. $\mathrm{Nu}$ var vi ikke sene til at komme bort fra dette Sted og ned til Dybbøl. Hen paa Formiddagen, da Skydningen var holdt op, kjørte vi ned til Stranden for at hente vore Vogne, og derpaa kjørte vi hjem. Medens vi da kjørte op ad Landevejen, begyndte Prøjserne allerede at transportere danske Fanger ad Flensborg til. Hvad der ærgrede os meget, var også det, at i Morgenstunden, efter at Skydningen var holdt op, kom flere bekjendte Hjemmetyskere fra Broager Sogn langs ad Landevejen, vist nok for paa første Haand at glæde sig over den wstore« tyske Bedrift. - Der kunde være meget mere at berette om denne ulykkelige Krig; men da det ikke vil være vanskeligt at faa langt udførligere Skildringer af Forholdene den Gang, saa har jeg indskrænket mig til at omtale ovenstaaende mere personlige og stedlige Begivenheder. 


\section{Dansk Optant}

Det var med stor Uvillie, at den danske Befolkning maatte finde sig i de mange tyske Anordninger, der efterhaanden indførtes; men værst var det dog med Værnepligten. Der skete dog ingen Udskrivning før i 1867; men Aaret i Forvejen, nemlig i Sommeren 1866, gik der stærke Rygter om, at man tog de unge Karle til Soldat uden Session og enten de var duelige dertil eller ej. Enkelte Karle rejste straks til Danmark, og vi var en lille Flok her paa Skeldemark, hvoriblandt vor Nabo Peter Hansen, som stod rede til ogsaa at rejse; men Fader vilde have den Sag nærmere undersøgt, og medens vi Karle opholdt os ude paa Fjorden i en Baad for ikke at blive overrumplede af Prøjserne, kjørte han en Dag til Rinkenæs, hvorfra Rygterne var kommet, for at forhøre sig om, hvorvidt det var sandt eller ej. Han kom saa hen paa Eftermiddagen tilbage med den Besked, at der var ikke et sandt Ord i, hvad Rygtet havde fortalt. Vi slog os derfor til Ro indtil videre.

Det varede dog ikke længe, inden jeg og mange flere fandt det raadeligst at søge Udvandringstilladelse i Henhold til Wienerfredens Artikel 19 og rejse til Danmark $^{14}$. Det hed sig da, at naar man havde havt fast Ophold derovre og havde Bevis for at være indskrevet der, saa kunde man komme hjem igjen og opholde sig her som dansk Undersaat. Paa min Forespørgsel hos Kancelliraad Fischer, Herredsfogden i Broager, hos hvem jeg fik min Udvandringstilladelse udstedt, om, hvor længe han mente, man skulde være derovre, for at det kunde antages, at man havde havt fast Ophold, svarede han, at ca. 14 Dage vel maatte være tilstrækkeligt. Jeg rejste den 21 . Juli, og for at have bekjendte Folk at komme til, blev det aftalt, at jeg skulde rejse til min gamle Skolelærer Vesterlunds Svigersøn, forhenværende Andenlærer N.R.Kjær i Skelde, som nu var Skolelærer og Degn i Øster Ørum, et Par Mil Nordøst for Vejle. Der blev jeg godt modtaget, og Kjær var mig behjælpelig med at faa en midlertidig Plads. Det blev hos Gaardejer Chr. Pedersen, Espekjær paa Daugaard Mark. Med et Bevis fra denne Mand paa, at jeg havde taget Plads der, attesteret af Sognefoged Povl Pedersen i Daugaard, tog jeg saa til Horsens for hos Herredsfogden at afgive Erklæring om at ville bevare min danske Undersaatsret i Henhold til ovennæunte Art. 19 i Wienerfredstraktaten og endvidere indmelde mig i den derværende Lægdsrulle. Samme Dag (den 13. Aug.) var Andreas Hollensen og Chr. Petersen fra Mølmark der i samme Anledning.

Paa Espekjær blev jeg til den 9. Oktober, saa rejste jeg hjem, meldte mig hos Herredsfogden i Broager og kunde saa efter Myndighedernes daværende Opfattelse blive herhjemme som dansk Undersaat. Der var efterhaanden kommen mange flere hjem paa samme Maade, og vi troede at kunne være trygge, indtil vi først i December Maaned samme Aar fik Ordre til at forlade Landet, 
dersom vi vilde bevare vort danske Undersaatsforhold; i modsat Fald vilde vi være at anse som prøjsiske Undersaatter. Jeg rejste derfor straks, den 4. December, og kom igjen til Skolelærer Kjær. Der blev jeg saa i nogen Tid, og bl.a. tærskede jeg hans Indavling.

I Julen besøgte jeg min Ungdomsven, Degn og Skolelærer Hans Jørgen Hansen i Sir ved Holstebro. Han var en Arbejdsmands Søn i Broager, omtrent jævnaldrende med mig, og havde tjent hos os en Sommer som Dreng og passet Kvæg. Efter sin Konfirmation fik han hos Degn Brodersen og Pastor Schleppegrell gratis Forberedelse til at komme paa et Seminar. Det blev Blaagaards Seminar, han kom til, og efter at have taget en udmærket Eksamen, fik han straks bemeldte Embede, som han endnu sidder inde med. ...

Hos Hansen var jeg omtrent en Uge, og medens jeg var der, blev han forlovet med en Lærerinde, Ludovika Gundelach, som han senere ægtede. Hansen var en dygtig Lærer og var meget afholdt af Befolkningen. Bl.a. holdt han Aftenskole for unge Karle, hvilket ikke var meget almindeligt den Gang. Naturvidenskab var ret hans Yndlingsemne at tale om, især Fysik og Kemi, hvilket var aldeles nyt for mig. Han vakte Lysten hos mig til at komme paa Højskole; men jeg opgav dog Haabet derom, indtil jeg et Aars Tid efter under et Besøg hjemme blev yderligere paavirket dertil. Det var en Aften, jeg gastede Rasmus Tychsen i Dynt, som var paa Askov Højskole den Vinter og nu var hjemme i Juleferien. Han kunde fortælle saa kjønt om, hvad der gik igjennem Undervisningen, at det var ikke til at modstaa. En Betænkelighed, som jeg havde ved at komme paa en Højskole, nemlig at jeg syntes, jeg var for gammel til at sidde paa Skolebænken, hævedes nu ogsaa, idet Rasmus Tychsen og flere andre Karle her fra Egnen, som var der, var endnu ældre end jeg. Jeg omtalte dog endnu, saa vidt jeg mindes, ikke min Lyst til at følge deres Eksempel, til mine Forældre.

\section{Herregårdskarl i Ørum og Daugård}

Kjær skaffede mig Plads hos daværende Løjtnant, senere Etatsraad Eckhard paa Ørumgaard i Nærheden af Ørum By. Jeg skulde være der paa samme Vilkaar som en Lærling fra Landhusholdningsselskabet, der var der; kun fik jeg ikke Kammer for mig selv, ligesom jeg kom til at spise sammen med de øvrige Karle og Daglejerne, medens Landbrugslærlingen spiste sammen med Mejeribestyreren. Jeg fik dog Løn i Lighed med 3die Aars Lærlingene, nemlig 40 Rigsbankdaler eller 90 Mark. I det hele havde vi egentlig ingen større Fortrin for de øvrige Karle, idet Arbejdet, som forlangtes af os, var akkurat 
det samme. Kun fik vi af Forvalteren Bockenheuser lidt Vejledning $i$ at føre Arbejdsjournal, og af Eckhardt selv blev vi holdt til at skrive nogle egenhændige Afhandlinger om landøkonomiske Emner, som han opgav os. Jeg husker bl.a., at vi skrev om forskjellige Slags Ukrudts Udryddelse, om Enges Anlæg og Forbedring o.s.v. Alt dette maatte vi selvfølgelig gjøre i vor Fritid, og saa saa han det efter og rettede det en Søndag Formiddag en Gang imellem, naar vi havde noget færdigt. Dernæst vilde han give os lidt Vejledning i Landmaaling; men det indskrænkede sig til højst 2 Gange. ...

Den 1. November $1867 \mathrm{kom}$ jeg i Tjeneste paa Gaarden Daugaard i Byen af samme Navn. Jeg blev Forkarl og fik i Løn for et Aar 72 Rigsbankdaler eller 162 Mark, hvilket ansaaes for en god Løn den Gang. Gaarden var ca. 160 Tønder Land stor, og der holdtes Landbrugsskole der. Der var 16 Elever, som hovedsagelig var Sønner af Folk, der var »uden for Bondestanden«, som man tidligere ofte udtrykte sig. ...

Foruden Forstanderen J.B.Krarup, som var Gaardens Ejer, var der en Landinspektør Lindhard der som Lærer, og en Gang om Ugen kom Dyrlæge Sander Larsen (fra Hornum, saa vidt jeg husker) der og gav Undervisning i Husdyrlære. Der holdtes Eksamen. Professor B.S.Jørgensen fra Landbohøjskolen i Kjøbenhavn var der som Eksaminator. ...

\section{Askov Højskole}

Eckhardt paa Ørumgaard kom ud en Søndag, da jeg var der ovre, og spurgte mig, om jeg vilde paa Højskole, og da jeg svarede ja, sagde han først, at han syntes ikke, jeg trængte saa meget til det; men da jeg saa sagde, at jeg mærkede bedst selv, hvor meget jeg trængte til Oplysning, saa svarede han, at jeg skulde saa da ikke tage hen paa den første den bedste Højskole, og han vilde da særlig anbefale Søgaards Højskole ved Vamdrup, om hvilken han mente, at den maatte have forholdsvis gode Lærerkræfter, fordi den understøttedes af en Forening af større og mindre Landmænd. Men ellers syntes han ogsaa godt om Vinding Højskole. Det blev dog ingen af disse to; hvorimod jeg, efter at have raadført mig med min oven omtalte Ven, Hansen i Sir, valgte Askov Højskole. Hansen skrev flere lange Breve til mig for at retlede mig i denne Sag, ligesom han, da jeg endelig havde besluttet mig, skrev et Par lange "kemiske Breve«, som han kaldte dem, for at forberede mig ogsaa paa dette Omraade. Han sendte mig først Johnstons "Katekismus i Agerdyrkningskemi«, som han opfordrede mig til at læse igjennem, og naar jeg saa stødte paa noget, som jeg ikke kunde forstaa, saa skulde jeg skrive til ham, for at han da kunde give mig nærmere Forklaringer. Alt dette gjorde, at jeg kom ret vel 
forberedt til Højskolen i Askov først i November Maaned 1868. Paa Rejsen dertil mødtes jeg efter Aftale med min Fader og Broder i Kolding, da der var et og andet at tale med hverandre om, og de medbragte tillige Sengeklæder til mit Ophold paa Højskolen. Ved denne Lejlighed fik jeg et stærkt Indtryk af min Faders tiltagende Svaghed. Bl.a. mindes jeg ogsaa, at han fortalte, at han af nogle medrejsende var bleven gjort opmærksom paa, at Højskolen i Askov var meget "grundtvigiansk «, hvilket han var meget urolig over, da han var inde paa, at dette var rent sekterisk. Jeg beroligede ham, det bedste jeg kunde; men det var dog først, da jeg var hjemme i Juleferien, at jeg ved at fortælle om, hvad vi havde for paa Skolen, fik Lykke til at forsone baade Fader og Moder med den grundtvigske Skole.

Paa Højskolen blev jeg helt overrasket ved at træffe flere Bekjendte hjemme fra. Især glædede det mig at komme paa Skolebænk sammen med min fordums Skolekammerat, Philip Sibbesen fra Gammelgab. Ogsaa Jens Jørgensen i Gammelgab og hans Broder samt Peter Andersen fra Skelde glædede jeg mig ved at træffe der. Desuden var der to Karle fra Dybbøl, nemlig Jørgen Clausen fra Dybbøløsten og Anders Christensen, som Jørgen Zachariassens Kone var gift med første Gang. Lidt hen i Vinteren kom Hans Frederiksen fra Egen, en Sønnesøn af min tidligere Husbonde, til Skolen. Vi var saaledes forholdsvis mange hernede fra paa Askov Højskole denne Vinter. Der kom i det hele taget mange sønderjydske Karle paa Højskole den Gang, hvortil jo den stærke Udvandring bidrog saa meget. Dette gav siden Stødet til, at saa mange andre fulgte deres Eksempel, nemlig gjærne først de Udvandredes Søskende og dernæst Venner og gode Bekjendte. Jeg har ogsaa altid havt den Overbevisning, at Udvandringen til Danmark trods alle de Ulemper, der er blevne en Følge af den, har havt den største Betydning for Danskhedens Bevarelse hos os. Ja, først paa Højskolerne er det gaaet op for mange unge Mennesker, hvorfor de var danske, og dette har saa igjen øvet Indflydelse i de Kredse, hvor tidligere Højskolelærlinge er kommet til at færdes. Jeg er ogsaa vis paa, at dersom dette ikke var kommet, saa havde det seet sørgeligt ud med Danskheden hernede. Hvor meget bidrog ikke ogsaa Udvandringen til at fjærne den Ringeagt over for Bondestanden i Danmark, og navnlig da i Jylland, som der vitterlig endnu var en god Del tilbage af.

Skjønt jeg som før bemærket kom ret vel forberedt paa Højskolen, var det dog i mange Henseender slet ikke saaledes, som jeg havde forestillet mig. Jeg havde aldrig tænkt mig, at man, endog i min Alder, kunde sidde paa Skolebænken og følge med i Undervisningen med et saadant Liv og en saadan Lyst, som det snart blev Tilfældet. Og så alt det vækkende, alle de nye Tanker, der vaktes hos én; det var noget, jeg aldrig havde drømt om. Dertil kom den fulde Tilfredsstillelse af den Kundskabstrang, man var mødt med, og som yderligere 
fremkaldtes. Jeg maa oprigtig udtale, at mit hele Syn paa Livet blev helt anderledes end tidligere, og nu syntes jeg ret, der var noget at leve for. Der var nogle og firs Elever paa Skolen den Vinter; de fleste boede paa Skolen; men nogle boede hos Lærer Nutzhorn og nogle andre Steder i Byen, hvor de ogsaa fik Kosten. Jeg boede paa Skolen og havde bl.a. Kammer sammen med Brødrene Jens og Hans Jørgen Jørgensen. Vi havde paa Kammeret, navnlig om Aftenen, megen Glæde af at tale sammen især om Schrøders Foredrag over Historie og Mytologi, hvilket vi nu var enige om, var det bedste paa Skolen. Jeg mindes ogsaa saa tydeligt, at mange Gange om Middagen, naar Schrøder havde endt sit Foredrag, saa kom H.J.Jørgensen hen til Ph. Sibbesen og mig og sagde: »Det var ellers noget godt noget, Du! Hvad?« Men ogsaa Fengers Undervisning var meget værdifuld for mange af os, særlig ogsaa for mig. Hans Foredrag i Fysik og Kemi »slugte« jeg med Begjærlighed. Det var ellers svært at følge med; men jeg fik Lov til at gaa med til hans Foredrag med Laboratorieforseg et Par Gange om Ugen om Eftermiddagen for viderekomne Elever, og dette hjalp noget til at komme til bedre Forstaaelse af Kemien. Jeg skrev et kort Udtog af hans Foredrag om Kemi paa Kladde, og det samme gjorde $\mathrm{Ph}$. Sibbesen ved hans Husdyrlære, og saa laante vi hinandens Kladde til at skrive rent efter.

Ligeledes skrev jeg et kort Udtog af Schrøders historiske og mytologiske Foredrag, dog kun efter Hukommelsen lige efter endt Foredrag. Hos Nutzhorn var det særlig Undervisningen i Dansk og i Sang, der fængslede mig. Fjerdelæreren Jørgen Madsen havde Skrivning, Regning, Landmaaling og Nivellering med os, og ham yndede vi meget, ogsaa for hans kammeratlige Omgang med os.

Jeg fik desværre et stort Skaar i mit Højskolebesøg paa Grund af, at jeg blev syg af en Lungebetændelse, som jeg efter Lægens Mening havde paadraget mig en Dag, da jeg eksperimenterede med en Klorforbindelse. Jeg var syg i flere Uger, og da det slog stærkt til Hovedet, saa havde det til Følge, at jeg led af Nervesvækkelse i nogen Tid derefter. Vel kom jeg paa Skolen igjen $i$ nogen Tid før dens Slutning; men den bedste Tid for mig var dog den, der gik forud for Sygdommen. Der var stærkt Tale om under Brevvekslingen mellem mine Forældre og mig, at jeg skulde have forladt Skolen, saa snart jeg var rask nok dertil, da de nok var bange for, at min Sygdom var kommen af Overanstrengelse paa Skolen; men Lærerne, som jeg talte med derom, raadede mig til at blive, og dette blev jeg rigtig nok senere glad for.

Som en Afslutning paa Højskoleopholdet blev vi indbudt til et Møde hos Bonden og Lægprædikanten Peder Larsen Skræppenborg i Dons ved Kolding. Foruden Askov Højskoles Elever var der ogsaa Eleverne fra Højskolerne i Vinding, Gjedved og Testrup tilligemed samtlige Lærere indbudte. Det blev et 
prægtigt Møde. Alle Forstanderne holdt Foredrag, og der blev sunget baade énstemmige og flerstemmige Sange. Vi blev beværtede med Kjødsuppe, Kaffe og Brød af Peder Larsen; han havde bl.a. slagtet en Ko i denne Anledning.

\section{Gårdejer i Skelde}

Da jeg kom hjem, meldte jeg mig først hos Herredsfogden i Broager og et Par Dage senere (d. 3. April) hos Landraad Matthiesen i Augustenborg, hvor jeg, ligesom mange andre Optanter, blev meget velvilligt modtaget. Jeg afgav Erklæring om at ville indtræde $\mathrm{i}$ det prøjsiske Statsforhold igjen, og denne Erklæring blev taget til Protokols og underskrevet af mig. Jeg fik derefter Ordre til at møde paa Sessionen i Sønderborg d. 15. Juni samme Aar (1869); der blev jeg oversat $i$ den saakaldte Ersat $z=$ Reserve, 2den Klasse og blev aldrig indkaldt til Tjeneste. Jeg fik fra nu af de fulde statsborgerlige Rettigheder lige saa vel som de tilsvarende Pligter. Trods dette var jeg ikke saa ganske vel tilfreds med det foretagne Skridt. Jeg syntes nemlig, det var saa vankelsindet, saaledes at vandre frem og tilbage, og det blev endnu værre, da der en Maaneds
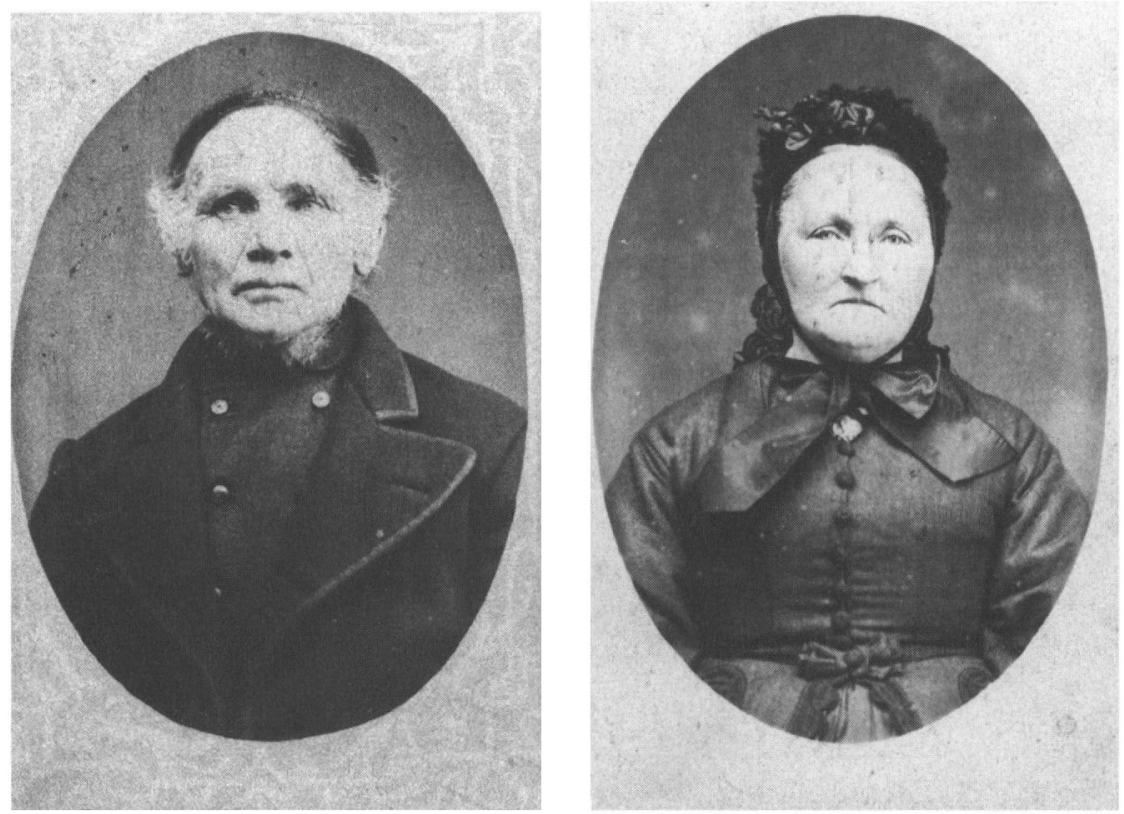

Andreas Andresens svigerforaldre var gårdejer i Egen Jergen Vrang (1809-79) og hustru Marie, hvis fodenavn også var Vrang (1819-1907). Fot, i privateje. 
Tid efter min Hjemkomst blev bekendtgjort, at alle de udvandrede kunde komme hjem og opholde sig her som danske Undersaatter, hvilket hidtil havde været os forment. Hvis vi vilde vende tilbage, maatte vi nemlig før den Tid være prøjsiske Statsborgere. Senere, da de danske Undersaatters Kaar hernede blev trangere, blev jeg dog glad ved min statsborgerlige Stilling.

$\mathrm{Nu}$ kom der efterhaanden flere og flere af de udvandrede hjem. Det varede ikke længe, inden tidligere Højskoleelever fandt hverandre, og navnlig kom flere af os jæunlig i Besøg hos hverandre her i Sognet. Jeg husker en Udtalelse af min Moder til sin Søster Ingeborg fra den første Tid, da vi begyndte med disse Sammenkomster: »Jeg gider dog saa gjærne sidde og høre, hvad de Karle taler med hverandre om. " Det var senere ogsaa en ganske selvfølgelig Sag, at mine Søskende skulle paa Højskole. Mine Søstre kom ogsaa begge til Askov; men min Broder havde ingen Lyst dertil og kom aldrig paa nogen Højskole.

Jeg blev nu i Hjemmet for stedse. Fader var bleven mere svag, og min Broder udvandrede til Danmark en Maaneds Tid efter min Hjemkomst, nemlig d. 1. April 1869. Med Faders Svagelighed tog det mere og mere til, indtil han døde d. 2. December 1869. Det var Tæring, han døde af, næppe 52 Aar gammel. Han var dog ikke sengeliggende til Stadighed mere end de sidste 23 Uger. Et meget stort Følge fulgte ham til Graven; der var 50 Vogne i Ligtoget. Sangforeningen »Harmonien« i Broager, hvis Formand han havde været i flere Aar indtil sin Død, mødte bl.a. i vort Hjem og sang Salmen: "Hvo ved, hvor nær mig er min Ende«, og daværende Præst Reuter holdt en meget god og trøstefuld Tale også i Hjemmet. Paa Kirkegaarden ledsagedes hans Baare af Sørgemusik, og hans Grav var kjønt smykket med Grønt af kjærlige Hænder. Fader var i mange Henseender en afholdt Mand i Sognet, hvilket jeg maa erkjende at have nydt meget godt af i mit Forhold til aldre Folk. I Følge Faders Bestemmelse bestyrede jeg Gaarden for Moder indtil d. 1. April 1872. Sommeren i Forvejen blev der, ligeledes efter hans Bestemmelse, hovedsagelig paa min Bekostning indrettet en Aftægtsbolig til Moder i den søndre Lade i 4 Fag ved den østlige Ende.

Min Forlovede kom i 1865 d. 1. November over at tjene hos Gaardejer Peter Andersen i Mølmark som Indepige og var der i 1 1/2 Aar. Derefter tjente hun i 1 Aar, altså fra 1. Maj 1867 til s.D. 1868 hos mine Forældre. Saa kom hun hjem og forblev hjemme med Undtagelse af et Ophold paa Askov Højskole sammen med min Søster Marie Sophie i Sommeren 1871, indtil vi i Foraaret d. 23. April 1872 blev gift.

Brylluppet stod efter den Tids Skik i vort $\mathrm{Hjem}$, og da det var ret stort, var begge Loer, Vognhuset og en Stue fuldt besatte med Gjæster. Vi slagtede en Ko dertil, som jeg selv havde kjøbt og fedet (rigtig nok med Moders Korn) og min Svigerfader gav os en fed Kalv. Vi dansede efter den Tids Skik i 
Loerne, og det var der selvfølgelig ingen, der tog Anstød af. To Dage før Brylluppet holdtes den saakaldte Brudesengsdag eller, som den ogsaa kaldtes, "Flæskeaften«. Da kom den største Del af Mændene med hver en Skinke eller undertiden Penge i Stedet for, sædvanlig 6 Mark. Naboerne og de nærmeste i Familien var indbudte til at "passe op«, som det kaldtes, og desuden kom sædvanlig alle de unge, som var indbudte og vilde med til Brylluppet, ogsaa den Aften. Der blev først drukket Kaffe med Tvebakker til og et par Kaffepunse bagefter, derpaa spiste vi Skinke og drak Vin til, og saa begyndte Dansen. Det var ofte lige saa muntert den Aften som paa selve Bryllupsdagen. Dagen efter gjordes saa Forberedelserne til det egentlige Bryllup, hvilket de mange omtalte "Oppassere" havde at besørge. Konerne havde jo alt, hvad der hørte til Madlavningen, at besørge, medens Mandene under "Skafferens" Ledelse gjorde Loer og Lader i Stand, for saa vidt dette ikke var sket til Brudesengsdagen, savede Brænde, tærskede Tvebakker i en Sæk til Bollerne i Suppen m.m. Der var nu egentlig ikke meget at bestille for Mændene.

Paa Bryllupsdagen opvartedes der med Suppe og Kjød og, efter et Ophold, med Skinke. Efter nok et Ophold fik vi Steg, hvorved det især gik løs med Vinen. Endelig fik vi, endnu førend vi gik fra Bordet, Risengrød med Smør i og »Ungvin« til at dyppe i. Senere, efter at Dansen var begyndt, fik vi Kaffe, og derefter gik det løs med Kaffepunse skiftevis med Dansen. Dagen efter Brylluppet mødte alle Oppassere igjen til Middagsmad og Kaffe. Der var saaledes megen Tidsspilde ved Hjemmebryllupperne, men det var jo Skik og Brug, og tog man det fra den gemytlige Side, saa kunde der ogsaa komme noget godt ud deraf. Det sidste Hjemmebryllup her i Byen var Lorens Jakobsens her paa Skeldemark i 1896. I 1893 havde vor Nabos, Hans Christensens Sønner, Frederik og Christian, Bryllup hjemme kort efter hinanden. Til disse nævnte Bryllupper brugtes der dog et stort Telt, hvilket var blevet helt almindeligt for adskillige Aar siden, naar det var i Sommertiden. Nu holdes alle større Bryllupper i Krohusene mod en vis Betaling pr. Person. - Min Broders Bryllup holdtes hos os i Marts 1874, og ligeledes min Søster Sophie Maries i Oktober 1876. Min Søster Maria Sophies holdtes i Hjemmet i Dynt d. 21. April 1874. ...15

\section{Krig og Stormflod}

I 1870 under den fransk-tyske Krig havde vi Indkvartering i nogen Tid af 4 tyske Feltartillerister med deres Heste. Vi gjorde ogsaa adskillige Krigskjørsler, særlig med Faskiner af Buskværk fra Skodsbølskov til Dybbølskanserne, som blev sat i Forsvarsstand. For Resten berørtes vi jo ikke videre af denne Krig, uden for saa vidt, at der blev gjort Indkaldelser til Militæret. Her fra Byen 
var bl.a. af de ældre Jakob Nissen og Hans Peter Jensen, Henrik Jensens Fader i Skeldgaardskobbel, med. Den sidste døde i denne Krig. Af de yngre, som var med, blev Jens Thomsen, en Broder til Handelsmand Chr. Thomsen, skudt. ...

I 1872 oplevede vi den store Stormflod d. 13. November, som vi blev temmelig føleligt berørt af. ...

Foruden den Skade, som Højvandet gjorde paa vor Mark, fik vi det ind $\mathrm{i}$ 2 Kornlader, hvor det nederste Lag ødelagtes. I et Kornhæs og et Høhæs, som stod sydøst for Huset, der hvor der nu er Abildgaard, stod Vandet ca. 11/2 Alen højt. Desuden druknede 11 Faar, som gik i Nørlyk og blev indespærrede af Vandet i det sydvestlige Hjørne ved Abildgaarden og Vejen. Der stod den Gang et temmeligt højt Dige øst for Abildgaarden. Endvidere væltede der 56 Bistader, som stod i Haven, og blev ødelagte. Vandet stod højest omtrent Kl. 7 om Aftenen; da naaede det op til 2-3 Tommer under det 3die eller næstøverste Trappetrin ved Stuehusdøren. I Aftægtet stod det ca. 6 Tommer over Gulvet, saa vi maatte bære nogle af Moders Møbler ind i vort Stuehus, medens vi fik de øvrige sat op, saa at de ikke stod i Vandet. I begge Loer laa tærsket Korn, som vi fik travlt med at faa baaret op paa Loftet, før Vandet kom ind. I Stalden begyndte det at komme ind af Dørene, og vi var belavede paa at trække Køerne andet Steds hen, hvis det skulde blive fornødent. Der var endog i den Anledning komne flere Mænd fra Byen her ud. Vi var næsten omgivne af Vand paa alle Sider af Huset, kun ved det nordvestlige Hjørne ved Vaskekamret og Brændselsladen var det tørt. Det var ret trist, saaledes som det saa ud. Vi talte nok af og til om, at nu kunde det da vist ikke stige højere; men det var jo allerede saa langt over, hvad vi nogen Sinde havde oplevet eller hørt omtalt, at man kunde jo ikke vide, hvor Grænsen skulde være. Glæden var derfor stor, da Vandet hen paa Aftenen begyndte at falde. Inden Sengetid var det allerede faldet saa meget, at det var et Par Favne uden for Leddet ved Dammen. Om Morgenen havde vi dagligt Vande. ...

Skaden, der var sket, blev overalt takseret. For mit Vedkommende beløb den sig til 600 Mark. Ved en Indsamling over hele Landet indkom der saa mange Penge, at jeg for min Part fik udbetalt 300 Mark. Fiskerne, som mange Steder var helt ruinerede, fik deres Tab forholdsvis godt erstattet, og der var enkelte Steder, f.Eks. ved Vemmingbund, hvor de ret kom paa Fode derved. Foruden Penge blev der ogsaa indsamlet og uddelt en stor Mængde Klæder m.m. til de vandlidte. Her i Kommunen faldt der, foruden 2 Huse paa Kragesand, et Par der, hvor Dampskibsstationen nu er, og et ved Skelde Kobbelskov.

Det tørre Korn af vort Hæs fik vi kjørt ind, og det vaade fik vi saa meget tørret i det paafølgende gode Vejr, at det kunde lade sig tærske paa en Maskine, som jeg laante dertil hos Peter Philipsen. Vi fik nemlig først selv en Maskine 
til Tærskning i 1873. Da Kornet var for vaadt til at faa malet, lod jeg det tørre hos Grynmølleren i Dynt; derefter brugtes det til Svinefoder. Paa samme Maade bar vi os ad med det nederste Lag Korn i Laderne, da vi først naaede saa vidt med Tærskningen. Det var nemlig saa heldigt, at Vandet naaede ikke helt igjennem Laget, saa at det meste af Toppen var nogenlunde tør. Ved denne Stormflod blev vi belært om, hvad vi ikke havde vidst tidligere, at vor Gaard ligger lavest her paa Skeldemark.

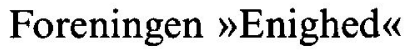

Den 10. Januar 1872 stiftedes en Foredragsforening for Broager Sogn og Omegn, kaldet »Enighed «. Stødet til dens Oprettelse var givet af forhenværende Overlærer Chr. Fr. Monrad og flere i Flensborg, hvor de havde en lignende Forening ${ }^{16}$. Planen dertil drøftedes først en Aften hos Peter Philipsen af ham, Lorens Hansen i Skeldegaardskobbel og mig. Vi sammenkaldte derefter en Del Mænd til et privat Møde hos daværende Gjæstgiver Jens Hansen i Broager, og Tanken slog godt an. Peter Philipsen havde været selvskreven til Formand; men da han var dansk Undersaat, blev det mig, der kaaredes til at overtage dette Hverv. Dyrlæge Thøjsen, Skodsbøl, blev dog, uagtet han ogsaa var dansk Undersaat, valgt til Sekretær, men blev senere afløst af Gaardejer Kr. Mikkelsen sammesteds, og Lorens Hansen blev Kasserer. Foreningen blev, overensstemmende med Lovene, anerkjendt som en privat Forening, der ikke vilde drøfte offentlige Anliggender, og blev derfor stillet uden for Politiets Tilsyn. Da der ved hemmelig Afstemning (Ballotement) vaagedes over, at vi ingen tysksindede Medlemmer fik optaget, saa kunde vi røre os temmelig frit med Tale og Sang ved vore Møder.

Vi holdt Møde en Gang i hver Maaned om Vinteren, sjældnere om Sommeren. Foredragsholdere fik vi dels her fra og dels fra Danmark. Jeg fik fra L. B. Poulsen i Bovlund ${ }^{17}$ en Liste over Højskolelærere, Præster og andre Mænd i Danmark, som var villige til at komme herover for at tale. Vi indrettede os i Reglen saaledes, at naar der kom Mænd derovre fra for at holde Foredrag, saa talte de baade i Bovlund, i Flensborg og hos os. Af Mænd, der har holdt Foredrag hos os, skal nævnes: Jens Langkjær, som i nogle Aar var Forstander paa Sandbjærg Højskole, Monrad, Lærer Holdt ${ }^{18}$, Gustav Johannsen ${ }^{19}$, Lærer West og Direktør Bredsdorff, alle fra Flensborg, L. B.Poulsen fra Bovlund og Mads Jensen i Jægerup, nu i Haderslev. Fra Kongeriget mindes jeg følgende: Højskoleforstander Schrøder og Lærer Nutzhorn fra Askov, Forstander for Jelling Seminarium, Pastor Madsen og Lærer Holm sammesteds, Præsterne Johannes Møller og Johansen samt daværende Friskolelærer Morten Eskesen 
i Odense, Friskolelærer Klaus Berntsen ${ }^{20}$ fra Fyen, Pastor Lange fra Nyborg, Pastor Johannes Clausen fra Ryslinge, nu i Vonsild, Højskoleforstander Carl Greve fra Grundtvigs Højskole, Forfatterne Carl Rosenberg og Fr.Vinkel Horn fra Kjøbenhavn og Pastor C. Hostrup fra Hillerød, senere i Kjøbenhavn. Adskillige af Foredragsholderne overnattede hos os, hvilket vi havde megen Glæde og meget Udbytte af.

Undertiden taltes der eller læstes op af P.Philipsen, P.Thøjsen og Smeden Chr.Jakobsen i Broager. At Sangen plejedes flittigt, maa ikke forbigaaes, og der er ingen Tvivl om, at derigjennem fik de gode Sange en stor Udbredelse her i Omegnen. Vi havde en Sangbog af Lohmann, som blev Grundlaget for den senere saa navnkundige blaa Sangbog. Foreningen vandt en stor Tilslutning; den talte til en Tid over 200 mandlige Medlemmer, for den allerstørste Del her fra Sognet. Møderne holdtes i Begyndelsen skiftevis i Skelde Kro hos Chr.Thomsen og i Skodsbøl Kro hos Peter Petersen, Tørveskipper kaldet, senere ogsaa hos Gjæestgiver Nis Skov i Broager. Et enkelt blev ogsaa holdt

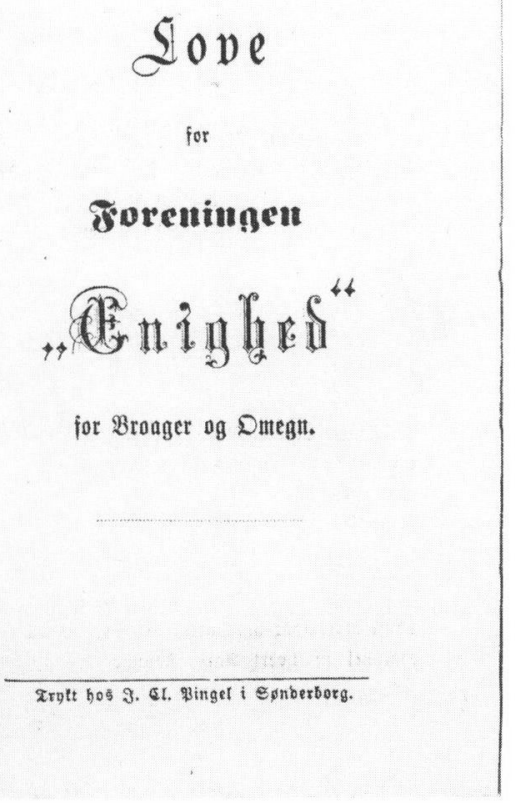

De trykte vedtagter for Foreningen "Enighed" for Broager og Omegn findes i foreningens arkiv $i$ Landsarkivet $i$ Aabenraa. 
hos P. Tychsen i Broager (Jes Jakobsen). Møderne var altid godt besøgte. Man kunde ofte se meget gamle Folk, som ellers sjældent kom nogen Steds, sidde og glæde sig ved Sang og Tale. Præsterne og enkelte andre holdt i Reglen kristelige Foredrag, medens det ellers altid var folkelige Foredrag, der holdtes. Det hele forløb stedse fredeligt og ordentligt, og der var aldrig Udsvævelse med Drikkeri efter Møderne. Vi havde det omtrent saa frit, som naar det havde været paa kongerigsk Grund.

Dog, dette kunde vel ikke blive ved under de herværende Forhold. Den ydre Anledning til Foreningens Opløsning blev et Besøg, som vi havde af Foredragsforeningen "Enigheden « i Flensborg i Sommeren 1874, der var 240 Gæster ialt. Dette vakte sagtens for stor Opsigt, idet vi hentede hele Selskabet med Vogne i Egernsund og, efter at vi havde drukket Kaffe hos Skovs i Broager, foretog en samlet Spadseretur til Smølvold. Paa denne Tur blev vi anholdt af 2 Gendarmer paa Broager Gade og adspurgt, om vi havde Tilladelse til denne Udflugt, der var at anse som en offentlig Procession; men da ingen af os havde tænkt derpaa, besluttede Gustav Johannsen og jeg, som Førere for Selskabet, os til at søge Tilladelse hos Herredsfogden til at fortsætte. Eskorteret af Gendarmerne, som gik en paa hver Side af Gustav Johannsen, gik vi da hen til Herredsfogden og fik den ønskede Tilladelse, hvorefter vi kunde fortsætte. Efter Udflugten havde vi en Fællesspisning hos N.Skov, ved hvilken der blev talt og sunget under stor Begejstring. Da der var pyntet med Blomster og Grønt i Salen, forlangte Gendarmerne, at den prøjsiske Fane skulde ogsaa ophænges der; men da vi ingen saadan kunde skaffe, saa hentede Gendarmerne en hos Kommuneforstanderen Fritz Ihle og fik den med stor Besvær anbragt i Salen. Lidt efter sang Flensborgerne Sangen: Højt paa en Gren en Krage sad.

Efter Sammenkomsten blev Bestyrelsen stævnet i Forhør hos Herredsfogden, som meddelte os, at Foreningen herefter vilde blive anset som en Forening, der drøfter offentlige Anliggender og følgelig vilde komme under Politiets Tilsyn, samt at vi skulde slette en Paragraf i vore Love, hvorefter Kvinder havde Adgang til vore Møder. Dette sidste havde nu Herredsfogden ingen Ret til at foreskrive os, idet han fejlagtigt gik ud fra, at det var en politisk Forening. Alligevel mente Bestyrelsen, at som Sagerne nu stod, og navnlig naar vi ikke skulde faa Lov til at have Kvinder med til Møderne, saa maatte vi hellere ophæve Foreningen. Dette blev ogsaa besluttet paa et Foreningsmøde kort efter. - Fra den Tid af begyndte Hjemmetyskerne her paa Egnen at spille Herrer. Paa Grund af deres Faatallighed og maaske noget af Undseelse ved at ignorere den danske Befolkning, som ikke havde skiftet Sindelag, havde de hidtil forholdt sig temmelig rolige.

Den Omstændighed, at jeg i min Stilling som Formand for den næunte 
Forening kom i Berøring med mange gode, fremragende danske Mænd, samt at jeg gjennem mit nabovenlige Forhold til P. Philipsen, der havde mange gode Forbindelser i Kongeriget, ogsaa fik Del i nogle af disse, har havt til Følge, at jeg i mit senere Liv er kommen meget ud iblandt Folk og er kommen til at tage Del i mangt og meget, som jeg maaske ellers næppe var kommen til. Til en Tid, navnlig i 70erne, holdtes der adskillige mindre Møder af Mænd fra begge Sider af Grænsen for at drøfte vor ulykkelige nationale Stilling. Til disse Mader var Philipsen og jeg som oftest indbudte. Paa Rejsen til et af disse Møder, som skulde afholdes i Kolding, kom vi i Kupe sammen med flere Herrer, som talte Tysk med hverandre. En af dem rejste med helt til Kolding og gik endog foran os ind paa Hotellet, hvor Mødet skulde holdes, og Philipsen og jeg blev enige om, at det maatte være en tysk Spion, saa vi var helt arrige paa ham. Ved Mødet fik vi saa at vide, at det var - Gustav Johannsen.

\section{Rejser til Danmark}

Naar der skulde gjøres Lystrejser til Danmark, saa har jeg ofte efter Opfordring været med til at samle Deltagere og som oftest tilligemed min Kone og Stedmoder gjort Rejserne med. En af de første Lystrejser var til Fyn i Sommeren 1874. Vi boede den Gang i Ferritslev og var til Kirke i Ryslinge og hørte Pastor Birkedal samt var til Fest i Rønninge-Søgaard Skov. Paa Tilbagerejsen var vi til 25 Aars Festen for Slaget ved Fredericia. Paa Rejsen dertil gjorde vi bl.a. Bekjendtskab med en ung Hjulmagersvend fra Ferritslev; det var nuværende Gaardejer Anders Hansen paa Rolfstedgaard, hvem vi senere er kommet saa meget i Berøring med og som navnlig har været en god Husbond for to af vore Børn, nemlig Jørgen og Sofie, ligesom hans Søn Hjalmar tjente hos os en Vinter. Jeg var ogsaa en Gang, nogle Aar derefter paa en Lystrejse, Gjæst hos Anders Hansen, der nu havde faaet Rolfstedgaard ved Giftermaal med Datteren der. ...

En tredie Gang har vi været i Besøg hos Gaardejer Hans Jensen i Nørrelyndelse, medens Johannes Clausen var Præst der. Da var der ogsaa en Del Sønderjyder med, og der holdtes Fest for os i Højby.

Den mest storartede Lystrejse, vi har været med til, var dog den til Vestjylland i 1884 d. 7.-10. Juni, hvori deltog ca 2.000 Sønderjyder. Deltagerne fra Als og Sundeved sejlede med Dampskib fra Sønderborg til Kolding, og derfra kjørte vi pr. Jernbane. Allerede i Kolding var Modtagelsen storartet. Et Dampskib, fuldt af Passagerer, mødte os et Stykke ude paa Fjorden og bragte os den første Hilsen, og i Kolding blev vi bespist med koldt Bord og Kaffe ved Borde nede ved Havnen. Vi fulgtes derpaa af en stor Mængde Mennesker til 
Banegaarden. At der blev holdt Taler og sunget og spillet er en Selvfølge. Ved alle Stationer var der gjort Stads af os, ligesom Dannebrog var hejst ved mange Gaarde og Huse langs med Banen, hvor vi kom frem. Ved Vejen Station gjorde vi Holdt, og Højskolepigerne fra Askov sang for os. Syd for Varde begyndte Modtagelsen ved Stationerne. Min Moder og min Moster Ingeborg, som skulde bo hos Pastor Engberg i Hemmet, steg af ved en Station lidt Nord for Varde, medens min Kone og jeg kom med til Lem Station, 1/2 Mil Syd for Ringkjøbing. Vi kom til at bo hos Gaardejer Anders Chr. Bloch i Lem, med hvem jeg havde gjort Bekjendtskab ved et Efteraarsmøde paa Vallekilde Højskole i 1882. Det var en Lørdag, vi kom dertil. Søndag Formiddag var vi i Kirke der i Byen, hvor Sognepræsten, Riemann, prædikede. Medens vi stod paa Kirkegaarden før Gudstjenestens Begyndelse, kom der en ung Mand gaaende, og Schrøder i Askov, hvem jeg lige havde hilst paa, sagde da: »Naa, der har vi jo Manden for det hele«. Denne unge Mand, som hed Peter Madsen og var en Vestjyde, kjendte jeg godt. Han havde flere Gange gaaet omkring her nede og solgt Bøger af kristeligt og folkeligt Indhold, og han skulde have undfanget Tanken om at faa den store Plan sat i Værk. Han var for øvrigt en ganske jævn Bondekarl, som færdedes iblandt os med stor Beskedenhed; men han havde Hjærtet paa det rette Sted.

Søndag Eftermiddag var vi til Møde i Velling Præstegaards Have, hvor der blev holdt flere gode Taler. Om Mandagen var vi ude ved Vesterhavet ved "Søndervig« paa Holmsland, vest for Ringkjøbing. Først var vi ude at se paa det store Vesterhav med dets storartede Strandbred og de høje Klitter inden for. Vi traf der ganske uventet min gamle Ungdomsven, den tidligere omtalte Degn H.J.Hansen i Sir, som rakte et Hoved op over de fleste Mennesker, og som derfor var let at blive var blandt den store Mængde.

Det var temmeligt stille Vejr den Dag, saa vi fik ikke det store Hav at se i dets Vælde. Til Gjengjæld var det jo et behageligt Vejr til det store Møde, som holdtes bag efter inden for Klitterne. Vi havde flere fremragende Talere, nemlig L.Schrøder, J.Nørregaard, C.Hostrup, L.B.Poulsen, Bovlund m.fl. Til min store Glæde holdt H.J.Hansen, Sir, ogsaa en lille god Tale. Det var et prægtigt Møde. Bag efter spiste vi af de medbragte Madkurve, nogle i Hotellet dér, men de fleste $\mathrm{i}$ dertil byggede store Telte. De Gjæster, der var længere Syd paa, holdt Fest om Søndagen ved Letbæk Mølle, og om Mandagen var de til Fanø, hvor Hovedmødet holdtes. Der var Moder og Moster med. Moder var da kommen hen til Pastor L. Nygaard, hvem vi var kjendt med fra et Besøg, som han og hans Kone havde aflagt hos P.Philipsen en Gang.

Tirsdag Formiddag samledes alle Sønderjyder med mange af deres Værter og andre Deltagere paa Torvet i Varde. Det var en vældig Forsamling, og der blev holdt flere gode Taler og sunget nogle Sange til Afsked. At der var sørget 


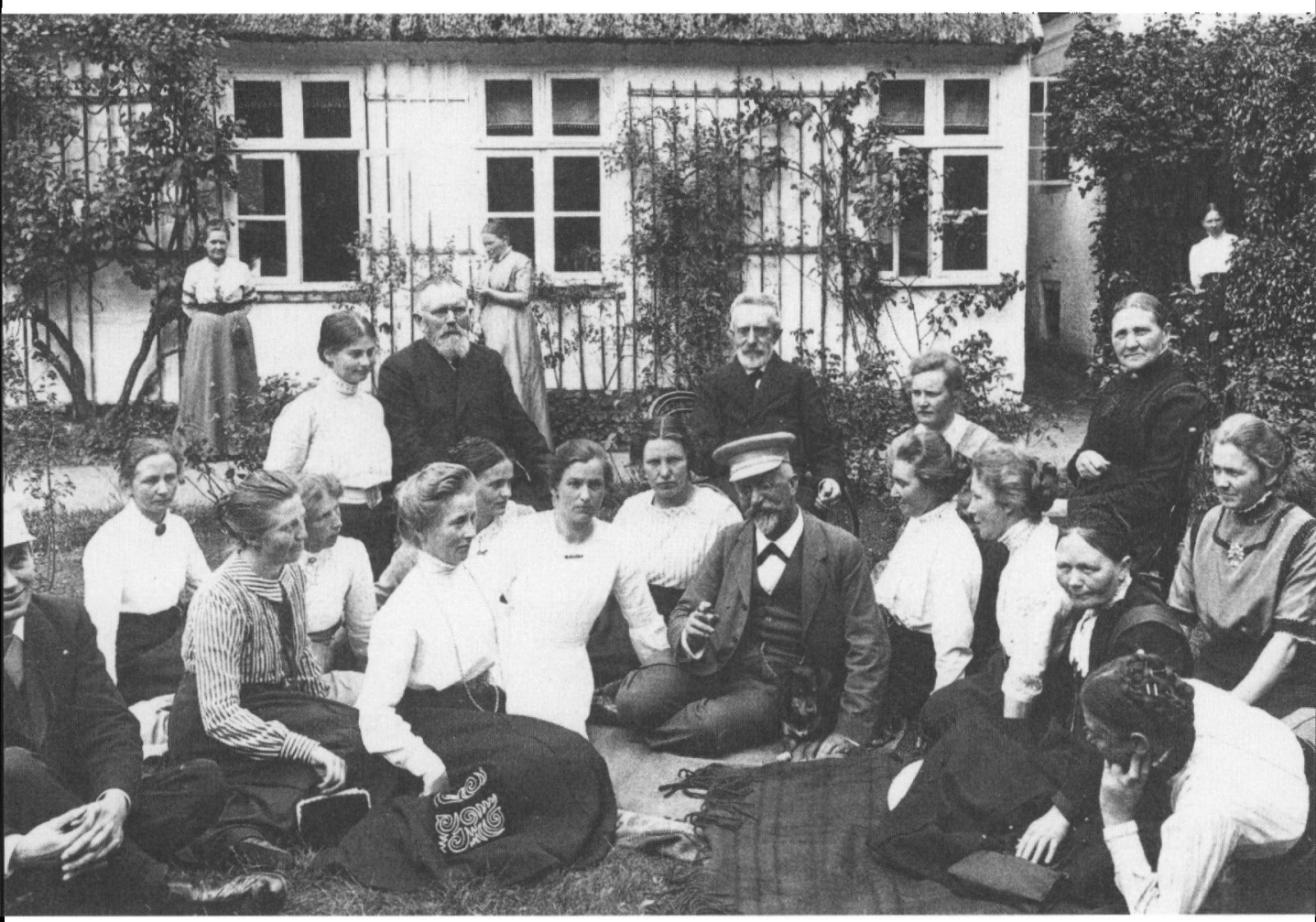

Andreas Andresen blev på Askov hajskole starkt praget af Grundtvigs kristelige og folkelige ideer. Blandt andet deltog han i de grundtvigske moder på Liselund. På ovenstående billede ses han $i$ en kreds i haven, siddende på en stol som nr. 2 fra venstre. Fot. i privateje.

for udmærket Musik og pyntet med Blomster, Grønt og Dannebrogsfaner ved alle Sammenkomster, er en Selvfølge. ...

Derefter rejste det store Tog hjem efter. Vi skulde igjen til Kolding og med Dampskibet. Der modtoges vi atter paa en meget kjøn Maade. Der var opdækket med koldt Bord til os i Ridehuset ved Slotsgaarden, og der holdtes atter Taler og blev sunget til Afsked. Alle var enige om, at det havde været en storartet Tur fra først til sidst. Der var en Aand og Feststemning over det hele, som aldrig vil glemmes af dem, der tog Del deri.

En saadan Tur var naturligvis Tyskerne en Torn i Øjet, og der paafulgte nu Udvisninger af enkelte af de danske Undersaatter, der havde været uforsigtige nok til at rejse med. Her fra Egnen var der navnlig en ung Kjøbmand fra Graasten, som blev udvist.

I 1887 var der en Lysttur til Samsø, hovedsagelig foranstaltet af Pastor Beck 
i Tranebjerg, som før 1864 havde været Præst i Stenbjerg Sogn paa Angel. Han blev imidlertid syg og døde kort Tid, før Turen skulde foregaa. Jeg blev af Hans Peter Hanssen i Nørremølle anmodet om at leje et Dampskib af Bruhn i Flensborg, som skulde sejle os dertil og tage os med hjem igjen. Vi kom til Anløbsstedet Koldby Kaas, noget førend vi var ventet; men L. Schrøder fra Askov, som vi, foruden nogle flere, havde faaet ombord i Fredericia, holdt saa en Tale for os, og der blev sunget, indtil Vognene kom for at hente os. Min Kone og jeg kom til at bo i Tranebjerg hos Gaardejer Rasmus P. Gylling. Det var en Lørdag, vi ankom der, og Søndag Formiddag var vi i Kirke og henne at bese Ruinerne af en gammel Borg der i Byen. Om Eftermiddagen var vi til Fest i Brattingsborg Skov paa den sydlige Ende af Øen. Det blev en dejlig Kjøretur paa den frugtbare $\varnothing$, og Festen var vellykket. Dagen efter rejste vi hjem. Vi havde godt Vejr til den temmelig lange Sejlads, der tog 5-6 Timer hver Gang.

I Tranebjerg Præstegaard traf vi sammen med Pastor Becks Søn, en ung filologisk Kandidat, med hvem vi var blevne bekendt paa Vestjyllandsturen, ved hvilken Lejlighed han giæstede de Folk, vi boede hos. Hans Fader havde nemlig tidligere været Præst i Lem, og da Præstegaarden i den Tid blev ombygget, boede Præstefolkene imens hos disse Gaardmandsfolk. ...

Bekjendtskabet med den unge Kandidat forte til, at han besøgte os samme Sommer, da han ønskede at undersøge Forholdene i Stenbjerg Sogn, hvor hans Fader havde vedligeholdt enkelte Forbindelser fra den Tid, han var Præst der. Det blev da Aftalen, at han skulde komme til os, saa vilde jeg ledsage ham paa en Tur derover. Vi sejlede saa en Morgen tidlig over Fjorden og turede rundt der ovre den hele Dag. Men den Danskhed, han ventede at finde der, var der ikke meget tilbage af, saa det var et temmeligt trist Indtryk, vi rejste hjem med.

I Sommeren 1872 var jeg tilligemed min Kone i Kjøbenhavn for at se den store Industriudstilling. Det var første Gang, vi havde set en Storstad, saa alene dette var meget interessant for os; men især de mange Seværdigheder saa vel som selve Udstillingen optog os stærkt. Vi var der i 4 Dage og boede privat hos en Detajlhandler C. Ketelsen i Grønnegade, hvis Datter havde været sammen med min Kone paa Askov Højskole. ...

\section{Landsbyen}

I 1872 foretoges Landets Opmaaling ${ }^{21}$ her i Byen. I 1876, fra 1.April af, afløstes de saakaldte Realbyrder til Præsten, Degnen og Kirken paa den Maade, at de blev sat til en fast aarlig Afgift, som betales sammen med de 
øvrige Skatter, saa at det hele falder bort efter 56/ $\frac{1}{2}$ Aars Forløb. Nogle Aar senere, i 1885, afløstes Realbyrderne i Kommunen, nemlig den saakaldte Grundhyre, som Kaadnerne havde at betale aarlig til Bønderne, og de saakaldte Gadepenge. Dette skete ved kontant Udbetaling d. 28. 4. 1885. Naar tidligere Gadepengene betaltes, hvilket fandt Sted i Forsommeren, holdtes det saakaldte Plovøl i Kroen. Der var 2 Fortalsmænd, som havde at indvarsle til Mødet og sørge for, at Reglerne blev overholdt. De indkomne Gadepenge blev drukket op, Drikkevarerne blev anskaffet i Fællesskab. Hvem der kom for silde, maatte betale Mulkt, og hvem der slet ikke mødte, maatte betale en større Mulkt. Ingen maatte forlade Selskabet, før »Lavet« var opgivet. Bl.a. bevilligedes et vist Kvantum Brændevin til Byens Karle, som i Reglen holdt Plovøl nogle Dage derefter. De havde ogsaa deres Fortalsmænd, der lige som Bøndernes skiftede hvert Aar. Her gik det endnu strængere til, og der var mange Regler, som skulde overholdes, for hvilket Straffen i Tilfælde af Overtrædelse i Reglen var at drikke en Snaps. Der var sjælden nogen af Karlene, der udeblev, og saasnart Drengene var konfirmeret, maatte de komme med. Om Aftenen var der Dans. Enhver Karl skulde bl.a. møde til Gildet om Eftermiddagen med en Buket, som Pigerne bandt til dem. Det var rene Drikkegilder, som det var godt, der ved den omtalte Afløsning blev gjort en Ende paa. Hvert Aar i November betaltes Grundhyren, som dog hovedsagelig deltes mellem Bønderne; men ellers var der lidt af de ovennævnte Regler ogsaa; men det angik dog ikke Karlene. En Levning af dette Stævne er det endnu brugelige saakaldte "Naboregnskab«. Af Gadepenge indkom der aarlig ca. 8 Mark, af Grundhyre ca. 2,48 Mark. Hver Bonde kunde efter et vist Afdrag tilkomme ca. 10,80 Mark.

Som det var Tilfældet næsten overalt, saaledes var det ogsaa her i Byen, at Smeden havde Land til fri Afbenyttelse, udlagt af samtlige Bønders Areal ved Jordfællesskabets Ophævelse i 1772. Desuden leveredes der af hvert Bol 6 Skjæpper Byg til ham aarlig paa Hellig 3 Kongers Dag, for hvilket Bønderne modtog "Kvittering" om Aftenen ved et Gilde, hvor der opvartedes med Kaffe og Tvebakker og Kaffepunse efter stor Stil til Kortspillet, som dreves traditionelt ved denne Lejlighed, samt Smørrebrød med Snaps til til Slutning. Det blev saaledes i Reglen rigtige Drikkegilder. For de næunte Ydelser af Jorden og Byggen fik Bønderne deres Smedearbejde gjort for en moderat Betaling. Naar Hestene skulde beslaas, mødte vedkommende Mands Karl gjærne om Morgenen tidlig for at trække Blæsebælgen og "slaa for «, naar Smeden lavede Skoene og smedede Stænger ud til at slaa Søm af. Derefter kom saa Hestene, sædvanlig alle samme Dag, og blev skoet. Jærnet og Kullene, som brugtes, skulde betales, men ellers fik Smeden ikke noget for dette Arbejde. Ligeledes hvæssede han Plovjærnene gratis og en lille Del af Vognbeslag skulde 
han heller ikke have noget for. Den Karl, der gik til Smedie, ogsaa naar der skulde Plovjærn »lægges paa«, havde Mellemmad og Snaps med, ogsaa til Smedesvenden. Der skulde ogsaa altid lidt Trækul med til Brug ved Smedearbejdet ved Hesteskoslaget. I 1886 solgtes Smedelandet, 12 Tønder Land, deraf 8 Tdr. til Jens P.Clausen og 4 Tdr. til Chr.Smidt, daværende Grynmøller, alt for 1.000 Mark pr. Tønde Land á 260 Kvadrat-Roder eller 16,640 KvadratAlen (Hamborger Maal). Dette beløb sig pr. Bol til Mark 521,72. Samtidig hørte Bygleveringen ogsaa op, og Smedearbejdet blev fra nu af udelukkende betalt med Penge.

\section{Landbruget i 1870-erne}

I 1873 foranstaltede Den sundevedske Landboforening, at der blev antaget en Mejeriassistent fra Danmark, Jensen hed han, til at hjælpe de Medlemmer, der ønskede det, paa Gled med at faa en bedre Mejeridrift indført. Han var hos os i September Maaned s.A. Det blev en hel Omvæltning i Mejerivæsenet, og det kan godt siges, at det er noget af det bedste, som Landboforeningen har foretaget sig. Det var Professor Segelckes og Docent Fjords Forbedringer paa dette Omraade, der toges til Rettesnor. Medens vi tidligere lod Malken staa alt for længe til Flødeafsætning, maatte der nu passes paa, at Mælken ikke blev sur, før den skummedes, og længere end $1 \frac{1}{2}$ Døgn kom den aldrig til at staa. Og medens vi tidligere kun kjærnede 2 Gange om Ugen om Sommeren og 1 Gang om Vinteren, maatte vi nu til at kjærne hver Dag, hvilket dog senere indskrænkedes til 4 Gange ugentlig. Dernæst blev Mælken vejet for hver Malkning, og der holdtes et fuldstændigt Mejeriregnskab, hvorefter vi navnlig hver Dag kunne kontrollere ikke alene Køernes Ydelse, men ogsaa Mælkens Anvendelse og især da, om Smørudbyttet var tilfredsstillende. Mejeriredskaberne blev eftersete og forbedrede, og Temperaturen i Mælkekjælderen reguleredes saa godt, det lod sig gjøre, lige som den passende Varmegrad under Kjarningen nøje maatte overholdes. Den Ulempe, der tidligere nok kunde forekomme, at man i den Tid i Efteraaret og Vinteren, naar mange Køer var gammelkende ${ }^{22}$, havde ondt ved at faa Smør og somme Tider slet intet fik, mærkede vi nu ikke mere noget til.

Paa denne Tid var Vandmejerierne ${ }^{23}$ stærkt i Ry, og hist og her, hvor Forholdene var passende dertil, indførtes denne Metode, dog var dette enkelte Steder ogsaa Tilfældet før Assistentens Komme. Ogsaa med Hensyn til Ostningen hjalp han os til en forbedret Fremgangsmaade. Bl.a. blev vi ogsaa indøvede i Brugen af Smør- og Ostefarve og i Behandlingen af Smørret, saa det blev os muligt at fremstille et nogenlunde ensartet Produkt. Vi kom senere 


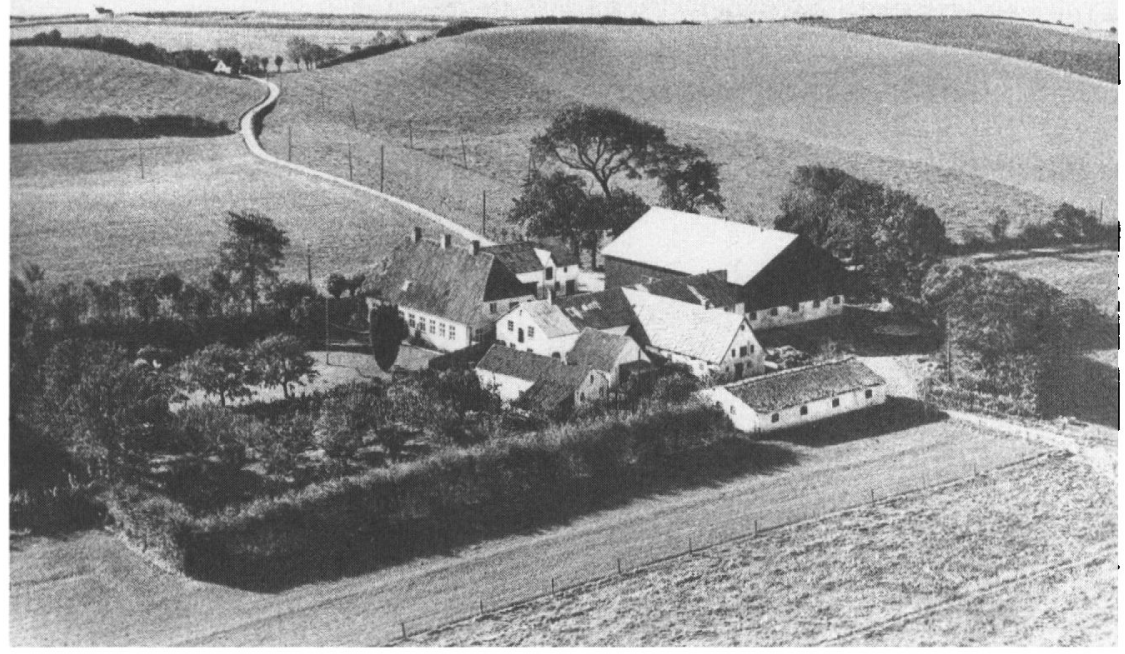

Billedet viser Rojhus, som gården så ud $i$ begyndelsen af 1950'erne, men bygningerne fandtes også $i$ 1903. hvor den store lade blev bygget. Oprindelig var der stråtag $i$ hvert fald på udbygningerne. Fot. $i$ privateje.

til at slaa Smørret sammen med P.Philipsen i en Del Aar, for at vi saa kunde levere et større Kvantum ensartet Vare og derved opnaa en lidt højere Pris, samt ogsaa fordi vi saa kunde slaa Smørret i Dritler eller Ottinger ${ }^{24}$ ogsaa i den Tid, da der kun var lidt Mælk. Smørpriserne var høje i Halvfjerdserne. Vi har til en Tid opnaaet indtil M. 1,50 pr. Pund, en Pris, som Smørret aldrig senere har kostet. Der var ogsaa enkelte, som fik et Par Penning mere, navnlig naar det var større Mærker. Det var naturligvis i den knappe Tid med Mælk, at Smørret kunde blive saa dyrt. Vi sendte vort Smør til Hamborg til Smørhandler Falck i en Del Aar. Senere sendte vi det direkte til England i nogen Tid.

En Gang, medens Assistent Jensen var her paa Egnen, fik han foranstaltet en Fællestur for nogle Mænd fra Sundeved og Als til Bovlundegnen, hvor han ogsaa havde arbejdet. Han havde lært Befolkningen derude at kjende som særdeles gode danske, dygtige og selvstændige Mennesker, hvem han mente, vi havde godt af at blive bekjendt med. Vi var der i et Par Dage og drog omkring fra Gaard til Gaard for at se os om og gjøre os bekjendt med de prægtige Folk. Vi var bl.a. hos Bunde Refslund den ældre og den yngre, Laust Arnum og L. B.Poulsen i Bovlund, hos Thomas Refslund og Christen Refslund 
i Vellerup, Jørgen Fausbøl i Branderup Mølle, Chr.Lautrup i Gestrup og Martin Fausbøl paa Mandbjærg. Jeg boede sammen med Hans Lassen i Lysabild hos Jørgen Fausbøl. Vi havde stor Glæde og et godt Udbytte af denne Rejse. Nogle Aar senere var jeg ogsaa med paa en Fællestur til Bovlund i Anledning af et større Møde, som blev holdt hos Poulsen. Desuden har jeg sammen med min Kone samt Peter Moos og Kone i Nybøl været kjørende helt til Bovlund med P.Moos's Befordring. Da var det særlig Poulsen, vi besøgte, men vi var også i Kirke der og i Smaabesøg nogle andre Steder.

I Halvfjerdserne var det gode Aar med forholdsvis høje Priser paa Landbrugsprodukterne. Derved forlededes vist nok ikke faa, særlig yngre Landmænd baade her og andet Steds til at gaa lidt vel flot paa med Anskaffelse af Maskiner og Redskaber og med Brug af Kunstgjødning uden Plan og fornødent Kjendskab til dens rette Anvendelse, hvilket det ved denne Tid endnu skortede paa. Ligeledes famledes der sikkert ved den Tid meget paa Fodringens Omraade. Der avledes for lidt af Roer, og Kraftfoderet, der gaves, var hovedsagelig Korn, Klid og Palmekager. Det var ikke sjældent, at der gaves 10 Pund pr. Ko og derover. Min Norm har dog ikke været over 8 Pund. Sidst i Halvfjerdserne og i Firserne blev det daarligere Tider. Priserne faldt paa Korn, Smør og Svin, saa Indtægterne formindskedes meget, medens Udgifterne væsentlig blev de samme.

\section{Andelsmejeriformand}

Da kom midt i Firserne Andelsbevægelsen paa Mejeriets Omraade fra Danmark hertil, og dette fik en heldig Indflydelse paa Landbrugets Rentabilitet. Det gav ikke blot en større Pris for Smørret, men ogsaa et forøget Smørudbytte, og dette gav igjen Stødet til en mere hensigtsmæssig Fodring. Roeavlen blev fremmet, saa det blev nu mere og mere almindeligt, at man dyrkede en hel Mark med Roer, og endvidere gik man snart over til at fodre udelukkende med Oliekager og Kraftfoder. Nu kunde man ogsaa bedre gjøre sin Beregning, om Fodringen var lønnende eller ikke.

Mejeriet her i Byen oprettedes i 1886. Der blev først, væsentlig efter Tilskyndelse af C.P. Wolff i Gammelgab ${ }^{25}$, forhandlet om at oprette et Mejeri for hele Sognet. Vi havde et Møde derom hos Gjæestgiver Holst i Broager, hvor jeg blev valgt tilligemed 5 andre Mænd til at undersøge Sagen. Det var den 9. Januar 1886, og den 12te s.M. var vi kjørende til Ullerup for at se deres Centrifuge-Mejeri. Jens Hansen i Midtskov var med og kjørte for os fra Broager af. Wolff var ogsaa med, men de øvrige husker jeg ikke bestemt. Derefter holdtes der atter et Møde i Broager, men det førte ikke til nogen 
Enighed om Sagen. Derimod kom nogle af os Deltagere fra Skelde og Dynt til at tale sammen om at oprette et Mejeri for begge disse Byer og maaske Gammelgab med. Senere blev der et Møde berammet i Skelde Kro til d. 6. Februar. Jeg blev anmodet om at føre Sagen frem, og Planen slog saa godt an, at det besluttedes at oprette et Mejeri-Interessentskab, og der tegnedes straks 280 Køer. En foreløbig Bestyrelse valgtes til at fremme Sagen, og, som det plejer at gaa, naar nogen er bleven Talsmand for en Sag, saa bliver han ogsaa gjærne hængende ved den, saaledes gik det ogsaa mig. Man valgte mig ind i dette Udvalg, og jeg maatte tillige overtage Formandsposten. De øvrige Medlemmer var: Carsten Jepsen, Hans Iversen, H.C. Bock og Rasmus Tychsen. Efter at vi havde forberedt Sagen noget og gjort et Udkast til Love, oprettedes Mejeri-Interessentskabet d. 17.de Februar i Skelde Kro, og den foreløbige Bestyrelse gjenvalgtes.

Jeg var ikke godt tilpas ved at have faaet dette Hverv, og navnlig var jeg betænkelig ved at have det omfattende Pengeregnskab i min Haand. Dog, jeg var jo valgt dertil, og jeg arbejdede derfor løs i Sagen i det bedste Haab. Den 22.-23. Febr. var Bestyrelsen til Angel at se et Par Andelsmejerier i Nærheden af Sørup, navnlig Svensby Mejeri, og gjorde os bekjendt med deres Afregningsmaade, som ogsaa blev Mønsteret for vor. Det var kun smaa Mejerier paa godt $200 \mathrm{~K} ø e r$, men de havde desuagtet et saa godt Resultat at opvise, at vi styrkedes yderligere i vor Overbevisning om, at Sagen var god. I Flensborg paa Bryggeriet saa vi en Ismaskine, men efter de Oplysninger, vi fik, kom vi til det Resultat, at det blev for dyrt. Den 25. Februar kjøbtes Byggepladsen til Mejeriet af Skrædder Andreas Christensen, eller rettere, vi kjøbte den lille Lykke neden for Andr.Christensen, som tilhørte Handelsmand Chr. Thomsen og byttede saa med hin mod at give 100 Mark i Bytte. Den 26. Febr. forhandlede vi med Fabrikant A.Jakobsen fra Firmaet P.J.Petersen i Haderslev om Mejerianlægget, efter at vi havde havt Tilbud fra et Firma i Aarhus (Fick) derom, og det overdroges endelig til den førstnæunte d. 24. Marts for 10.000 Mark og 400 Mark for at indlægge en Møllesten. Den 25. Marts begyndtes Brøndboringen ved Carsten Lassen i Smedeby. Bygningens Opførelse overdroges til Murmester M.Horn i Broager. Pengene laante vi hos Professor Esmark i Kiel gjennem hans Broder i Rinkenæs.

En Mejerist, der var hos Kjøbmand Weber i Broager for at slaa løst Smør sammen i Dritler, og som var kjendt med Centrifugedrift, lejedes til Mejeribestyrer. Det var den senere Gjæstgiver i Skelde, nu Gaardejer paa Skodsbølmark, Jørgen P. Jensen fra Horsensegnen. Den 23. August stod Mejeriet færdigt til at modtage Mælk til Behandling. Efter at der d. 13. Marts var tiltraadt 7 Mænd fra Gammelgab, bestod Interessentskabet af 57 Medlemmer med et Koantal af 750. Spændingen var stor blandt Folk over, hvordan det vilde gaa. 
Paa en lille Konfusion nær paa Grund af Bestyrerens Uvanthed med selvstændig Styrelse af et Mejeri, gik alting godt, og den 9. September havde vi den første Udbetaling, som var Udbyttet for de 8 Dage i August Maaned. Det var en hel Fornøjelse med denne første og de nærmest følgende Udbetalinger. Folk gjorde store Øjne, naar de hørte, hvor mange Penge de kunde faa, ja, enkelte tvivlede paa, at det kunde være rigtigt. Det maa jo erindres, at det var det første Andelsmejeri i Egnen, saa de fleste havde ingen rigtig Overbevisning om, hvor lønnende Foretagendet kunde være. Det nærmeste Andelsmejeri var i Skovby paa Als, og ellers var der ingen flere i Sønderborg Kreds.

Da vi havde ladet Mejeribestyreren uddanne paa Ladelund Mælkeriskole til at prøve Mælkens Fedtindhold efter Docent Fjords Metode, begyndte vi omtrent straks at betale Mælken efter denne Afregningsmaade, saa det var et af de første Mejerier paa denne Side af Grændsen, hvor dette blev indført. Vi havde da ogsaa den Tilfredsstillelse, at der i de første Aar var adskillige Mejeribestyrelser og et Par Mejerister her fra andre Egne for at giøre sig bekjendt med denne Foranstaltning, som senere blev helt almindelig. Dog gik man de fleste Steder, lige som vi, over til senere at bruge Dr. Gerbers Apparat, der udskiller selve Smørret i Stedet for, som ved Fjords, Fløden. Vi havde megen Tilfredsstillelse ved at have bragt Sagen saa vidt frem, og det paaskjønnedes ogsaa af alle og ikke mindst af de smaa Grundejere, som nu fik lige saa meget ud af deres Mælk, som de større, hvilket de langt fra var vant til. At Folk var tilfredse med mit Arbejde i Mejerisagens Tjeneste, gav sig Udslag i, at der paa den forste aarlige Generalforsamling efter Carsten Jepsens Forslag bevilligedes mig et Gratiale af 100 Mark for den Ulejlighed, jeg havde havt frem for de andre Bestyrelsesmedlemmer. Regnskabsvæsenet fik jeg Anvisning paa i det væsentligste af Mejeribestyrer H.P.Philipsen fra Ullerup, den Gang paa "Kildevæld" Mejeri ved Kolding, senere Fabrikant i Slagelse.

Trods den almindelige Tilfredshed, der var med Mejeriets Oprettelse, varede det dog ikke længe, før der sporedes Utilfredshed snart med det ene og snart med det andet, især angaaende Interessenterne i Byen i deres Forhold over for de øvrige med Mælkeleveringen. Senere opstod der ogsaa fra visse Sider Utilfredshed med Mejeribestyreren, hvilket efter min Overbevisning var ganske uden Grund, hvorfor jeg ogsaa blev ved at holde paa ham; men da Flertallet af Bestyrelsesmedlemmerne var imod ham, og vi saaledes ikke kunde blive enige om at leje ham paany, saa besluttede jeg at gaa af som Formand og Bestyrelsesmedlem, naar min Valgperiode var omme i Efteraaret 1890. Skjønt man viste mig den største Tillid ved at vælge mig enstemmigt paany, fastholdt jeg dog min Beslutning om at gaa af. Den 21. Marts 1890 var jeg tilligemed Carsten Jepsen til en stor Smørudstilling i Kiel. Paa Rejsen dertil erfarede vi, at Bismarck var gaaet af som Rigskansler. 


\section{Andre tillidshverv}

I Efteraaret 1882 blev jeg af Den sundevedske Landboforening valgt ind i en Kommission, der i sammen med en lignende fra Den alsiske Landboforening skulde undersøge forholdene angaaende Rentabiliteten ved Sukkerroedyrkningen og Oprettelsen af en paatænkt Sukkerfabrik for Als og Sundeved. Vi var først en Tur til Odense for at tale med tidligere Højskolelærer R. Fenger, der nu var Bestyrer paa et Par Gaarde i Bolbro ved Odense, som "De danske Sukkerfabrikker« ejede, ligesom vi også gjorde os bekjendt med Sukkertilvirkningen paa Fabrikken i Odense. Medlemmer af Kommissionen var foruden mig Jørgen Jensen, Snogbæk, nu paa Saksgaard i Ulkebølskov, Hans Lassen, Lysabild, Chr. Bladt, Tandsgaard og Hans Nissen, Viby.

Senere i Nov. 1883 var vi til Kjøbenhavn for at tale med Formanden for "De danske Sukkerfabrikker", Etatsraad Tietgen og Direktør Hagemann. Tietgen talte vi med paa Børsen, og af ham fik vi en Anbefalingsskrivelse med til et Par Sukkerfabriker paa Lolland, nemlig i Højbygaard og Nakskov, hvilke vi besaa et Par Dage derefter. Vi fik god Underretning og Besked om alt, hvad vi ønskede og mere til. I Nakskov havde vi tillige Anbefalingsskrivelse fra Tietgen til den bekjendte Erhard Frederiksen, som ogsaa var meget imødekommende mod os. Jeg maatte kort efter ved et Landbomøde i Nybøl ganske uforberedt aflægge Beretning om denne Rejse, hvorved jeg blev sat i en ikke ringe Forlegenhed; men ved hjælp af de Optegnelser, jeg havde gjort, reddede jeg mig ud af det.

I Sommeren 1883 var Kommissionen ogsaa i Hannover og Sachsen for at undersøge Sukkerroeforholdene; men der bad jeg mig fritaget for at rejse med. Derimod kom jeg med Wolffs Hjælp til at udarbejde en Redegjørelse for Kommissionens Arbejde og Syn paa Sagen, som blev trykt og omdelt til Landboforeningens Medlemmer d. 15. Septbr. 1883. Turen til Kjøbenhavn og Lolland skete altsaa et Par Maaneder senere. Der forhandledes derefter sammen med Alsingerne om Sagen i længere Tid, forskjellige Forhold angaaende Fabrikens mulige Anlæg undersøgtes af en anden dertil valgt Kommission, og en Beretning derom tryktes ligeledes og omdeltes; men paa Grund af Sukkerprisernes Dalen i det sidste Par Aar tilraadede Kommissionen deri at lade Foretagendet hvile indtil videre. Dette skete i Januar 1885.

I Sommeren 1883 sidst i Maj og først i Juni Maaned var jeg som Stedfortræder for Hans Lassen ${ }^{26}$ i Lysabild ca. 14 Dage i Provins-Synoden ${ }^{27}$ i Rendsborg. Jeg kom til den Erkjendelse, at jeg næppe var paa min rette Plads i denne Stilling og tog derfor ikke mod Gjenvalg til den næste Samling. Udgivelsen af en forbedret dansk Salmebog for Nordslesvig blev forberedt i denne Samling. Det var efter Forslag af Wolf, Gammelgab paa Provsti Synoden ${ }^{27}$, at jeg trods 


\title{
Beretning
}

\section{af den fundevedfke Santboforenimgs eldovala}

til

\author{
underiogelfe af Sorbolbene \\ veb

\section{Suterrodyraingen.}

\author{
Aflagt bro Lanbbomobet i Mnjol ben 5. Septbr. 1883.
}

Ubvalget har fogt at loje fin Dpgave, bets veb at fotte fig inb i bet $\$$ om ben foreliggenbe $\mathrm{Sag}_{\mathrm{g}}$ og bels veb, lammer meb ben aljifte Ranbboforenings ubvalg, at gjote fig beljents meb Sulterroebyriningen og tale meb foll i nogle af be Egne, boor benne 3nbus

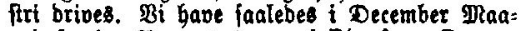
neb forrige gar oaret onre i Dbenfe og Dmegit, og i fibftafoigte Juli Maaneb have di foretaget en Reife til \$amnoper og Sabien.

Naar vi nu fulle giore Rebe for lanbbofor: eningen angaaenbe oor unberiogelje, jaa have vi troet at lunne giore bette bebit veb at opitille flere Sagen vebrorenbe Eporgsmaal til Bejua= relfe. Disfe Epargimaal ville ba vare:

\section{1.}

\section{Eroortnubaenbeagerbrug te $t \mathrm{t} a \mathrm{~b} \in \mathrm{l} t$ ?}

Naar Agerbruget ftal talbes rentabelt, faa noa man ifte labe fig noie meb, at naar man f. Er. iffe har mere $5 j$ jorb paa in Lanbeientom enb fra $\%$ til op tmob Walvbelen af bents Barbt, man ba lige tan faa fig igjennem; man maa berimtob forbre, at Eienbonmen fal forrente Gele fin Barbi. Saalange bette tite er $x$ ilfalbet, lan mant if lalbe Agerbrabetrentabelt.

Der ex vel nappe Mogen, fomt vil paaftaa,

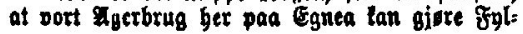

beft i faa Genfeente. Der lyber toertimob Rla: ber fra alle Eiber, at unber be nuowenbe for:

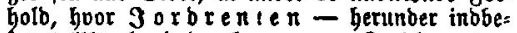
fattet salt, boab ber bonger paa \&anbbruget er faa hoi, er bet meget vanfteligt at errare fig fom 3orobruger. En Ertiendelfe af, at bet er faalebes. ligger forgorigt allerebe i ben 3nteresfe, meb hoiffen ben funbevebife og ben aliffe Land: boforening har taftet fig over sulterroebyrtning Sprrgsimaalet.

Men er bet ru faalebes, at vort Igerbrug $i$ itn nuoxrenbe frorm langtira tan lalbes ren: tabelt, jaa ligger bet nat at unberioge, hoab ber lan vare Erumben bertil. Et af $x_{0}$ maa

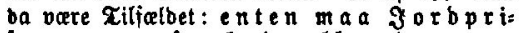
fernevareforboie, elter ber maa ox refeil oeb $D$ tift maaben.

soab nu bet fortite angacr, tia vifer bet. fig, at paa anbre Egne meb lignenbe flimatifte og 3orbbunbs: Forbolb fom vore, tan Mgerbru= get meget gobt forrente fig, uagtet Jorbprijerne unbertiben ere betybeligt hoiere enb ber. I noie Forbinbelfe hermed ftar forgagtringsof: giften, meb boilten Forbolbet omtrent er bet famme.

Raar bet altiaa faalebes lan pacifes, at 3orbpriferne ifte ubetingeterefor bie, faa maa berverefiloeb $\$$ rift maaben.

Detiom man fial betegne, buab ber et gien= nemgaaenbe $i$ bet ruparenbe Agerbrug $\mid$ Sun=

Andreas Andresens beretning om sukkerroedyrkningen blev afgivet den 15.september 1883. Tryksagen findes indklahet i Den sundevedske Landhoforenings forhandlingsprotokol i landsarkivet $i$ Aabenraa. 
min Delagtighed i Bestræbelserne for at faa oprettet en Frimenighed, blev valgt til dette Hverv. De danske Medlemmer af Fælles-Synoden i den nævnte Samling var foruden mig: Hans Nissen, Viby, Jes Nielsen, Kassø, Henrik Thomsen, Roost, And. Petersen Lund, Rejsby-Ballum, Konsul Amorsen, Haderslev, samt en pensioneret Lærer, hvis Navn jeg ikke husker. Medens jeg var i Rendsborg, blev vor Datter Anna født, og da det var mindre godt med min Kones Befindende bag efter, gjorde jeg en Rejse hjem.

\section{Hjemmet}

Vi havde det første Besøg af Gartner Ole Knudsen i den Tid. Ham var jeg bleven bekjendt med ved et Efteraarsmøde paa Vallekilde Højskole 1882. Dette Besøg gav Anledning til, at vi besluttede at omlagge Haven, hvorfor Ole kom igjen i Efteraaret 1883. Vi gjorde omtrent ren Bund i de gamle Frugttræer, der stod og plantede ny. Et gammelt Hegn ved den østre Side ryddedes bort, ligeledes et stort Stendige paa de to Sider af den gamle Kjøkkenhave, hvoraf Stenene kjørtes op i den gamle Mærgelgrav i Nørlyk. Jeg overlod Ole den nordre Del af Haven, den nuværende Kjøkkenhave, til eget Brug mod en lille aarlig Afgift, og han var her i ca 5 Aar, indtil han blev udvist og bosatte sig i Hejls i 1888 .

Vort Ægteskab er blevet velsignet med 8 Børn, som alle lever, medens dette nedskrives i Febr. 1910. Den ældste, Hans Christian, er født den 3. Februar 1873. Marie er født den 19. April 1875, Jørgen den 21. Februar 1877, Andreas den 4. Juni 1879, Sofie Marie den 28. April 1881, Anna Margrethe den 1. Juli 1883, Ingeborg den 25. Juli $1885 \mathrm{og}$ Margrethe den 7. August $1893 \mathrm{om}$ Natten K1. 3. Holdt over Daaben er: Hans af min Farbroder Peter Andresen, Marie af min Svigermoder, Jørgen af min Svigermoder paa Grund af, at Svigerfader var syg, Andreas af mig, Sofie af min Stedmoder, Anna ogsaa af min Stedmoder, Ingeborg af min Moster, Ingeborg Gregersen, og Margrethe af min Kone.

Hos saa stor en Flok Børn er det jo sjaldent, at der undgaaes Sygdomme i Opvæksten, og det er vi heller ikke sluppet fri for i vor Børneflok; men vi takker Gud for, at de er alle komne godt over det, saa vi i vor Alderdom ikke alene kan glæde os ved Lejlighed at kunne samles med dem allesammen, men at de ogsaa er sunde og muntre.

I Sommeren 1888 var den store Landmandsforsamling med Udstilling og Dyrskue, til hvilket jeg var med tilligemed min Kone og min Moder. Jeg rejste Dagen før de d. 19. Juli og førte vor Søn Andreas paa Kysthospitalet paa Refsnæs ved Kalundborg, og jeg kom saa efter Aftale sammen med dem i Roskilde for at følges med dem til Kjøbenhavn. Vi kom til at bo i Højskolefor- 


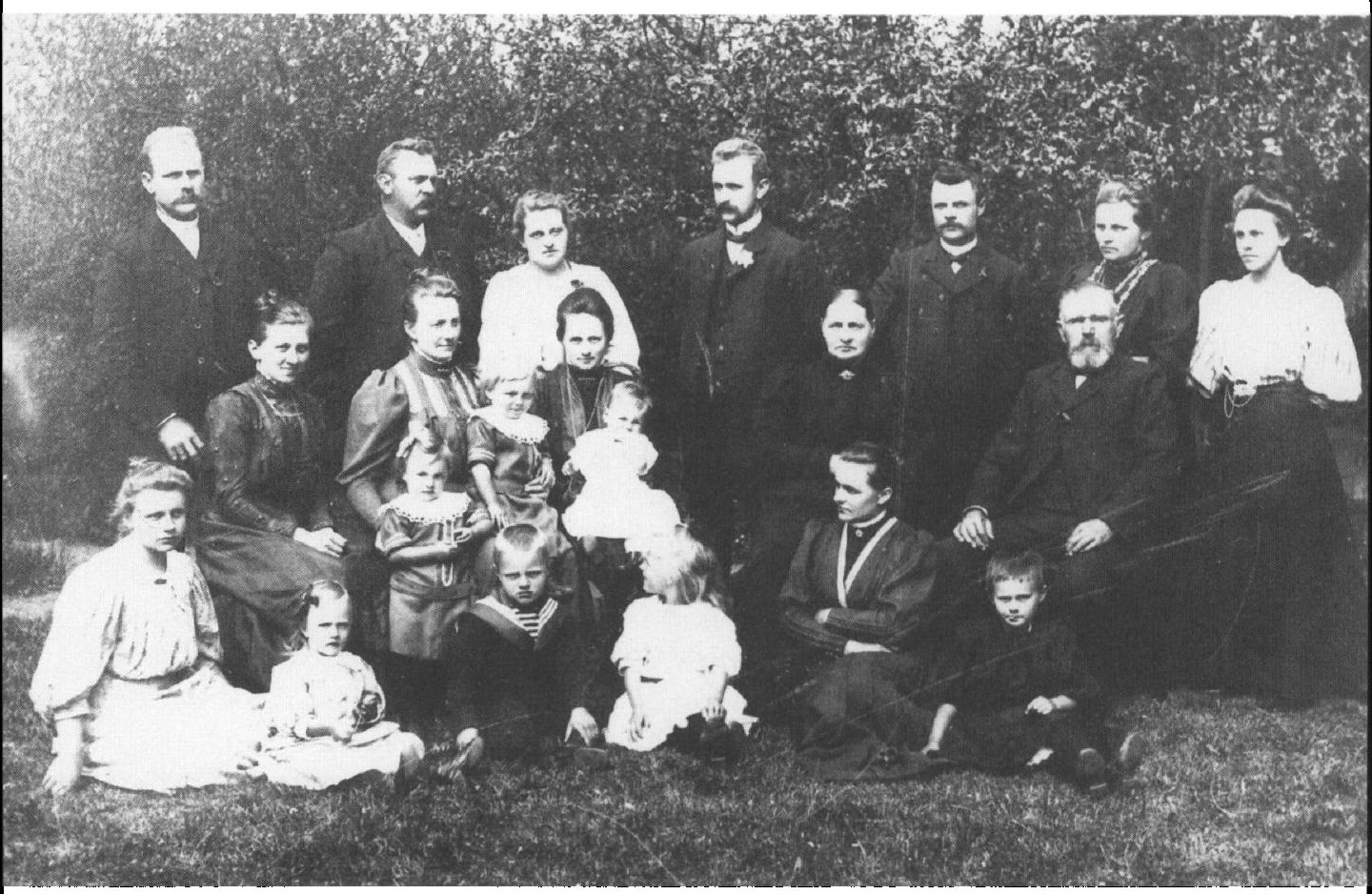

Andreas Andresen med hustru, born, svigerbarn og borneborn ca. 1909. Fot, i privateje.

eningen hos Hr. Falkenstjerne. Denne Udstilling er det mest storartede, jeg nogensinde har været med til. Vi var i Kjøbenhavn i 4 Dage. Paa Kysthospitalet var Andreas i ca 7 Maaneder. Den Øjensygdom tilligemed Udslet i Ansigtet, som han led af, var haardnakket. Jeg besøgte ham i Oktober Maaned, da var der ikke megen Forandring med ham endnu. Det var egentlig først efter Nytaar, at navnlig Øjnene begyndte at bedres. Den 26 . Februar hentede jeg ham som ret godt helbredet; men ca $2 \frac{1}{2}$ Aar derefter blev Øjnene daarlige igjen. Efter $\mathrm{i}$ længere Tid at have prøvet forgæeves med forskjellige Hjemmeraad, besluttede vi endelig i Maj 1892 at sende ham til en Øjenlæge, Dr. Eriksen i Aarhus. Der var han i ca 4 Uger og kom saa godt helbredet hjem.

Nationalt og kulturelt virke

Anledningen til, at vi fik ham dertil, var, at vi havde en Vandre-Lærerinde, Henriette $\mathrm{Gubi}^{28}$, til at undervise Børnene i Dansk, og hun var selv bleven 
kureret for daarlige Øjne af Dr. Eriksen. Hun tog ham selv med paa en Rejse til Holstebro. Før den næunte Lærerinde havde vi havt Vandrelærer, nuværende Boghandler Kasper Jensen i Broager, til at undervise Børnene. Han var her 2 Gange, hver Gang i ca 14 Dage, og ligesaa Frøken Gubi. Man kunde vel synes, at dette kunde ikke gavne ret meget; men det viste sig alligevel, at Børnene ved den dygtige og praktiske Maade, Undervisningen gaves paa, havde et godt Udbytte deraf. Det var naturligvis kun i Fritiden uden for Skoletiden, at det kunde lade sig gjøre. Men selv dette, som dog skulde synes at være en ganske privat Sag, fik ikke Lov til at gaa længere end et Par Aar, saa blev det forbudt.

Først i Halvfjerdserne havde P.Philipsen og jeg iøvrigt gjort et Forsøg paa at samle en Del danske Børn her fra Byen skiftevis i deres Hjem. Philipsen fortalte Fædrelandshistorie for dem, og jeg sang med dem, og det gik helt fornøjeligt, baade til Børnenes og deres Forældres Glæde. Jeg mindes saaledes, at hele Børneflokken kom en Dag, det var paa min Fødselsdag, og forærede mig en Tobakspibe. Men det varede ikke længe, før gamle Pastor Hansen ${ }^{29}$, (det var en Langfredag Eftermiddag) kom over til os, endog i fuldt Ornat, for at tale med os om at lade dette være. Han kunde, som han sagde, ikke lade Vorherre ligge rolig i sin Grav uden at faa gjort, hvad han kunde for at afholde os fra at fortsætte. Det var dog Synd for de stakkels Børn saaledes at vildlede dem, sagde han endvidere. Jeg lovede at ville tale med Forældrene om Sagen, men mente ellers ikke, der kunde være noget ondt $\mathrm{i}$ dette, naar det var med Forældrenes Minde. Et Par Mænd, nemlig Thomas Thomsen og Lorens Hansen, var derefter oppe hos Pastoren at tale om Sagen og foreholdt ham det formentlig uberettigede $i$ at gribe saaledes ind i Forældrenes Rettigheder; men det endte dog med, at vi fandt det klogest at holde op. Præsten lod sig nemlig forlyde med, at dette Foretagende skulde vel være en Frugt af en Foredragsholders Yttring i vor Foredragsforening om, at vi maatte se at modarbejde Skolen i Hjemmene, og saa frygtede vi for, at det derefter kunde komme til at gaa ud over Foreningen.

I 1883 døde Pastor Hansen. Jeg var Kirkeældste den Gang og var med at bære hans Lig til Graven. Jeg var ogsaa Kirkeældste Aaret efter, da vi havde Præstevalg første Gang efter den ny Anordning i saa Henseende. Pastor Reuter, der tidligere var Andenpræst her, blev valgt med 6/7 af Stemmerne, der afgaves, og Deltagelsen i Valget var endda stor. Han var nemlig den Gang ret godt afholdt som Prædikant, saa, skjønt der fra de bedste danske Folks Side blev agiteret meget imod hans Valg, fik Valget dog det ovennævinte Udfald. Mærkeligt nok faldt hans Yndest som Prædikant efter den Tid i en Grad, at Kirkebesøget ofte maatte siges at være meget tarveligt inden hans Død $\mathrm{i}$ Sommeren 1905. I hans Sted fik vi som Andenpræst Pastor Thiesen ${ }^{30}$, en ret 
dygtig Prædikant, men en uselvstændig Personlighed, som følte sig i høj Grad afhængig af Pastor Reuter. Han kom til Nybøl efter nogle Aars Forløb, og efter ham fik vi Pastor Schumacher.

Mit Forhold som Kirkeældste til Pastor, senere Provst Reuter, var i flere Henseender noget spændt; han var mig alt for spidsfindig at forhandle med, og der kunde ikke blive Tale om nogen Tilnærmelse mellem os i kirkelig Henseende. Det stadfæstede sig her for mig, hvad jeg stadig, siden jeg paa Højskolen kom til at tænke over vore kirkelige Forhold her i den danske Del af Sønderjylland, har været overbevist om, at en sand, kristelig Vækkelse ved de tyske Præster, som altid vil modarbejde os i folkelig Henseende, vil næppe nogen Sinde finde Sted. Efter min Opfattelse er der en vis Sammenhæng mellem det kristelige og det folkelige, som altid vil faa Indflydelse paa det kristelige Samfundslivs Udfoldelse.

Jeg har altid følt det som en kjær Pligt at være med til at støtte den danske Sag, hvor det fordredes, og jeg er derfor kommen meget ud iblandt Folk ogsaa i saa Henseende, lige som jeg ogsaa har mødt megen Velvillie blandt den danske Befolkning. Jeg har været med til Oprettelsen af Sprogforeningen i Aabenraa, Vælgerforeningen i Vojens og Skoleforeningen i Skærbæk. Jeg var Kredsformand i Sprogforeningen fra dens Oprettelse indtil 1902, da man gjorde mig til Optant ${ }^{31}$. I Vælgerforeningen var jeg Tillidsmand ogsaa indtil
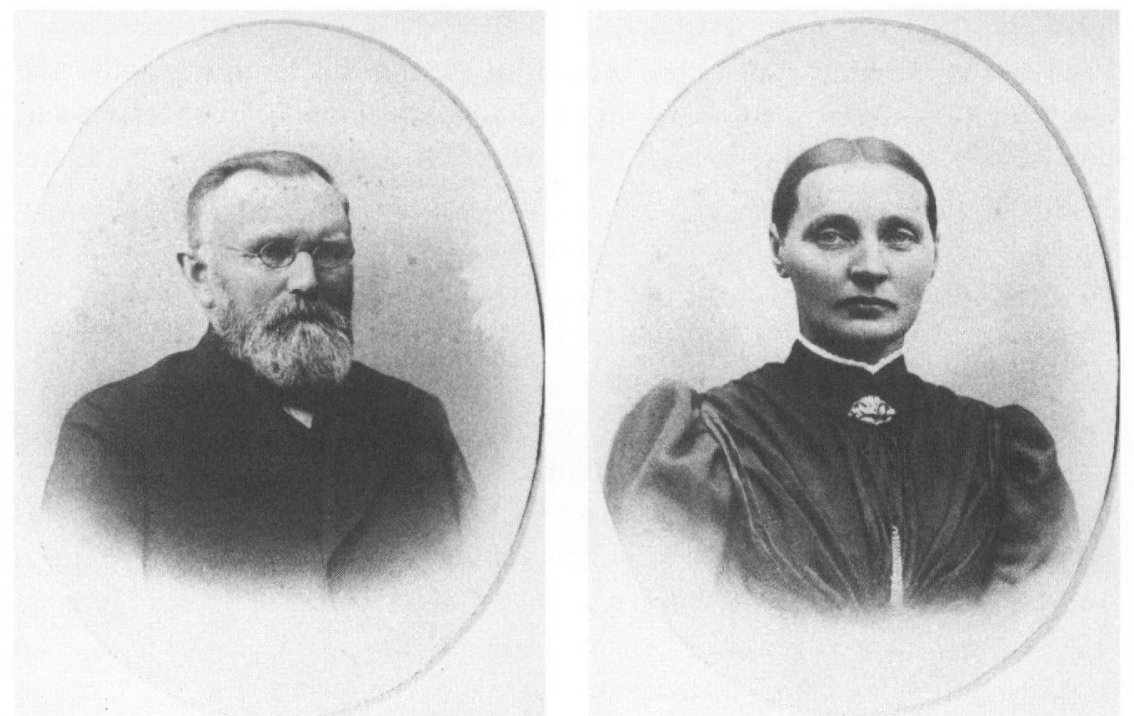

Andreas Andresen og hustruen Ane Margrethe f. Vrang (1846-1911). Fot. i privateje. 
samme Tid, og jeg var Medlem af Skoleforeningens Bestyrelse i flere Aar, indtil der paa Grund af de mange Retssager mod Bestyrelsen blev indført en anden Ordning, nemlig med en ganske faatallig Bestyrelse.

Jeg har rigtig nok ofte følt mig trykket af, ikke at have røgtet de mange Hverv, der er blevet mig betroet, samvittighedsfuldt nok. Villien dertil har det ikke skortet paa; men jeg kan nok ikke sige mig fri for nogen Efterladenhed til visse Tider, saa jeg har maattet tilstaa for mig selv, at der kunde være gjort mere for vor gode Sags Fremme, og dette kunde være sket om Arbejdet her, som saa mange andre Steder, havde været noget mere fordelt. - Jeg har været med til de fleste af vore hedengangne Repræsentanters Begravelse, nemlig H.A.Krygers i 1881, J.P.Junggreens i 1886, Gustav Johannsens i 1901 og Hans Lassens i 1896. Desuden har jeg været med til et Par fremragende danske Mænds Begravelse i Flensborg, med hvem jeg havde havt ikke saa lidt Forbindelse, nemlig de forhenværende Skolebestyrere: Monrad og Holdt. Vi har havt en hel Mængde Besøg af Folk, særlig fra Kongeriget, som har rejst her ovre for at gjøre sig bekjendt med Forholdene her. Der var en lang Tid, da en stor Del af saadanne Rejsende gjærne skulde til Skeldemark til Philipsens og os, naar de kom til Sønderborg og Dybbøl. Vi kjørte dem saa ofte omkring og kom til flere af vore Venner med dem. Senere er der blevet en Del flere, som er komne til at nyde godt af disse Besøg.

I Halvfjerdserne var jeg med til at oprette en privat Skole i Broager under Lærer Fr.Oehlerichs Ledelse. Den gik særdeles godt i nogle Aar med et stort Elevantal, og det kjendtes godt senere, at de fleste af dem, der havde gaaet $\mathrm{i}$ denne Skole, havde et godt Udbytte deraf og blev trofaste mod vor nationale Sag. Den ophævedes paa Grund af Oehlerichs uheldige økonomiske Kaar, men vilde næppe have faaet Lov til at bestaa ret længe paa Grund af Myndighedernes mere og mere strænge Fremfærd mod alt, hvad der var dansk. Afdøde Redaktør Jessen ${ }^{32}$ i Flensborg var Lærer her i et Par Aar, ligesom ogsaa hans Broder P. Jessen, forhenværende Lærer i Daler ved Tønder. Vi havde nogen Omgang med de 2 Brødre, idet de undertiden kom med til vore Aftenmøder, hvilket vi satte stor Pris paa, da navnlig den ældre Jessen (Redaktøren) ofte gav et godt Ord med i Laget. Den Kreds af Venner, som kom sammen i mange Aar til Aftenmøder, var foruden mig: P.Philipsen, Lorens Hansen, Skeldegaardskobbel, Philip Sibbesen og Jens Jørgensen i Gammelgab, Rasmus Tychsen og Peter Toft i Dynt og senere (efter hans Hjemkomst fra Jylland) Andreas Hollensen. Vi havde megen Glæde af disse Sammenkomster, hvorved vi læste op af gode Bøger, sang og samtalede om det oplæste. Vi kom sammen en Aften i hver Uge om Vinteren; sjældnere om Sommeren. ... 


\section{Frimenigheden}

Det er ikke nogen gammel kristelig Vækkelse, som ligger til Grund for Tilblivelsen af Frimenigheden i Sundeved. Det maa nærmest siges at være en Frugt af de danske Højskolers Indflydelse paa de unge Mennesker her fra Egnen, som i Tiden fra omtrent 1866 af have gjæstet saadanne.

Den grundtvigske Livsoplysning, baade i folkelig og kristelig Retning, havde grebet de unges Sind og fremkaldt Trangen til at søge at fortsætte den Udvikling, som de var blevne delagtige i, og som var bleven en Hjærtesag for dem. Dette lod sig, som det havde været ønskeligt, imidlertid ikke giøre ved de stedlige Præsters Medvirkning, da disse stode enten uforstående eller vel endog modvillige over for den vakte Trang. Derfor oprettedes som næunt allerede $i$ Januar 1872, væsentlig ved tidligere Højskoleelevers Medvirkning, en Foredragsforening i Broager Sogn, som lod afholde kristelige og folkelige Foredrag. $\mathrm{Da}$ jeg som Formand for denne Forening fik en Del Indflydelse paa, hvilke Foredrag der skulde holdes, maa jeg her bekjende, at jeg i Begyndelsen havde nogen Betænkelighed ved at lade afholde kristelige Foredrag paa Grund af, at dette ikke udtrykkelig var omtalt og planlagt ved Foreningens Oprettelse, og det tillige var tvivlsomt, om Folk syntes om at gaa med til opbyggelige Møder i Krohusene, som var de eneste større Samlingspladser ved denne Tid. Det viste sig imidlertid glædeligvis, at min Betænkelighed havde intet paa sig, og derfor fortsatte vi med afvekslende folkelige og kristelige Foredrag, efter som det tilbød sig.

Som Foredragsholdere, der har havt Betydning for det kristelige Livs Fremvækst hos os i denne Tid, skal nævnes daværende Lærer L. B.Poulsen i Bovlund og Rebslager Mads Jensen i Jægerup, samt af Mænd fra Kongeriget, der den Gang endnu uden Hindring kunde komme her og tale, følgende Præster: Johannes Møller og Johansen fra Odense, Lange, Nyborg, Johannes Clausen, Ryslinge, C.Hostrup, Hillerød, Madsen, Jellinge samt Højskoleforstander L.Schrøder, Askov.

Efter at denne Forening, som iøvrigt havde vundet stor Tilslutning, i Sommeren 1874 maatte indstille sin Virksomhed paa Grund af Øvrighedens Indgreb, var det nærmest kun en mindre Kreds af Mænd i Broager Sogn, som samledes skiftevis i Hjemmene en bestemt Aften i hver Uge, særlig om Vinteren, til Oplæsning af folkelige og kristelige Skrifter, Samtaler om det oplæste og Sang. ... En Gang imellem i Løbet af nogle Aar samledes en Del Familier, hvoriblandt ogsaa enkelte fra de andre Sogne i Sundeved, i private Hjem, naar Mænd som L.B.Poulsen, Mads Jensen og flere kom her og holdt kristelige Taler. Vi har ofte laant Hus til saadanne Møder, dels fordi vi havde god Plads, og dels fordi jeg var prøjsisk Undersaat, hvilket ikke var Tilfældet med de 
fleste af dem, der sluttede sig til. Ved saadanne Sammenkomster blev der ofte talt om det onskelige $\mathrm{i}$ at faa fastere Former for det kristelige Livs Pleje, og dette førte omsider i 1879 til Underhandlinger med Privatlærer Rasmus Thomsen $^{33}$ fra Anslet, den Gang i Bovlund, om at freste Bo iblandt os og være vor faste Ordfører. Vennekredsen her var bleven kjendt med ham ved en af de omtalte Sammenkomster, da han i Følge med Poulsen gjæstede os i 1878. Det blev dog ikke før i 1882, at Thomsen bosatte sig i Broager. Fra den Tid af holdtes der kristeligt Møde i Thomsens Hus, og med ham som Ordfører, hver Søndag, i den første Tid om Eftermiddagen efter Kl. 4, da saadanne Møder efter Myndighedernes daværende Opfattelse maatte sættes i Klasse med Møder af anden Art, Forlystelser m.m., som stred imod Helligdagsanordningen. Senere frafaldt man denne Opfattelse, og Møderne holdtes saa Søndag Formiddag. For Tilslutningens Skyld længere fra i Sundeved holdtes der siden ogsaa kristelige Møder en Søndag Eftermiddag i hver Maaned hos Chr. Hanssen i Nørremølle med R. Thomsen som Ordfører.

Det gik jævnt godt i nogle Aar; men saa blev Forholdene trangere for de danske Undersaatter (Optanterne), af hvilke der var ikke saa faa, som havde været med i Bevægelsen fra første Færd af og andre, der senere havde sluttet sig til. En Del af dem blev ængstelige ved at tage Del i Møderne. Dette var den væsentligste Grund til, at Thomsens Virksomhed indstilledes for saa vidt, at han flyttede til Nybøl, og der ikke længere blev holdt regelmæssige Møder. Paa denne Standsning i Udviklingen bødedes der dog ved, at der fortsattes med at afholde offentlige, kristelige Møder Tid efter anden i Nybøl Kro, hvilket der var begyndt med under Thomsens Virksomhed i Broager. I Forbindelse med disse Møder begyndtes der nu med, at Poulsen i Bovlund, der var bleven præsteviet, holdt Altergang (i Reglen Foraar og Efteraar) i Peter Moos's Sal i Nybøl efter forudgaaet privat Indbydelse blandt Vennerne dertil.

Smaamøderne i Broager Sogn, som standsedes, da R. Thomsen blev Kredsens Ordfører, var imidlertid blevet optagne igjen. De holdtes en Tid lang $i$ Enken Anna Zachariassens Bolig i Broager; senere er de blevne holdte skiftevis i Hjemmene med Tilslutning af et Par Familier uden for Sognet. Peter Philipsen har her hovedsagelig været den egentlige Leder, og Møderne fik et mere afgjort kristeligt Præg end tidligere. Senere blev der ved Siden deraf lejet en Sal ved Dynt Mølle, hvor der saa siden har været holdt kristeligt offentligt Møde en Søndag i hver Maaned med tidligere Vandrelærer Kasper Jensen fra Gjerup ved Tønder, nu Boghandler i Broager, som Ordfører.

Noget senere, i Sommeren 1899, byggedes et Forsamlingshus i Sottrup, hvor der nu og da ogsaa er blevet holdt offentlige kristelige Foredrag, bl.a. ogsaa i Forbindelse med Altergangen hos P.Moos i Nybøl, og fra den Tid af holdtes der sjældnere Møder i Nybøl Kro. Enkelte Gange har P.Philipsen senere 
foranstaltet saadanne baade der og andre Steder i Kredsen, navnlig ogsaa i de senere Aar i sin egen Forsamlingssal i Nybøl.

Ovennævnte R. Thomsen, som i 1889 rejste til Amerika og blev Præst i en dansk Menighed derovre, var imidlertid kommen tilbage (1895), og var bleven Præst i den nydannede Frimenighed i Haderslev. Han kom nu ogsaa undertiden, ligesom Frimenighedspræsten Lycke i Rødding, til Nybøl og holdt Altergang skiftevis med Poulsen og i Forbindelse med de offentlige kristelige Møder, som senere henlagtes til Sottrup Forsamlingshus. Der er ofte ved de snævrere kristelige Sammenkomster blevet forhandlet om Oprettelsen af en Frimenighed; men man manglede Mod til at begynde, vist nok begrundet $\mathrm{i}$ Frygten for, at der ikke skulde blive tilstrækkelig Tilslutning, naar endelig Skridtet skulde gjøres fuldt ud.

Da var det ved en saadan Sammenkomst efter et Møde i Sottrup Forsamlingshus paa Søndagen mellem Jul og Nytaar 1901, at en mindre Kreds, samlet hos Jørgen Bonefeld i Sottrup, efter Præst Thomsens Tilskyndelse besluttede at begynde. Otte Familier fra de forskjellige Sogne i Sundeved blev derefter enige om at rejse til Haderslev d. 2. Februar 1902 for at tale nærmere med Thomsen og nogle Medlemmer af Frimenigheden der om Sagen. De 8 Familier var: Jørgen Zachariassen, Dybbøl, Jørgen Bonefeld, Sottrup, Christian Andresen, Snogbæk, Johan Andresen, Ullerup, Peter Moos, Nybøl, Jens Jørgensen, Gammelgab, og mig tillige med samtlige vore Koner. Senere holdtes der flere private Møder samt forhandledes med Poulsen og flere, og endelig oprettedes der ved et Møde hos Peter Moos i Marts 1902 en Frimenighed for Sundeved og Omegn. Det besluttedes indtil videre at holde Gudstjeneste 2 Gange om Maaneden i Sottrup Forsamlingshus, efter at Frimenighedspræsterne Poulsen, Thomsen, Lycke og Jørgensen havde lovet at betjene Menigheden foreløbig.

Samtidig besluttedes det at bygge en Kirke, og den 30. Maj 1902 kjøbtes en Byggegrund af Gaardejer Jakob Christensen i Stenderup. Senere udnævntes et Byggeudvalg, bestaaende af: Gaard- og Mejeriejer Jørgen Zachariassen i Dybbøl, Gaardejer Peter Moos i Nybøl og Gaardejer Nis Sibbesen i Bøffelkobbel, med den førstnæunte som Formand. En Tegning til Kirken blev tilvejebragt ved Arkitekt M. Nyrop i Kjøbenhavn, og efter at Byggetilladelsen var indhentet, begyndtes der paa Byggearbejdet, som blev overdraget til Bygmester L.Grøne i Avnbøl som den lavestbydende. Kjørslerne forrettedes af Menighedsmedlemmerne og nogle andre velvilligt interesserede Beboere i Omegnen.

Grundstenen lagdes den 17. April 1903 af en af de aldste af Menighedens Medlemmer, Jens Jørgensen i Gammelgab, og Kirken blev rejst den 27. Juni samme Aar, saa den kunde indvies den anden Søndag i Advent, den 6. Decbr. 1903. Ved Indvielsen var der mødt en efter Forholdene ret talrig Forsamling. 


\section{Firmenighedskirke - Prøstegaard. Sundeved.}

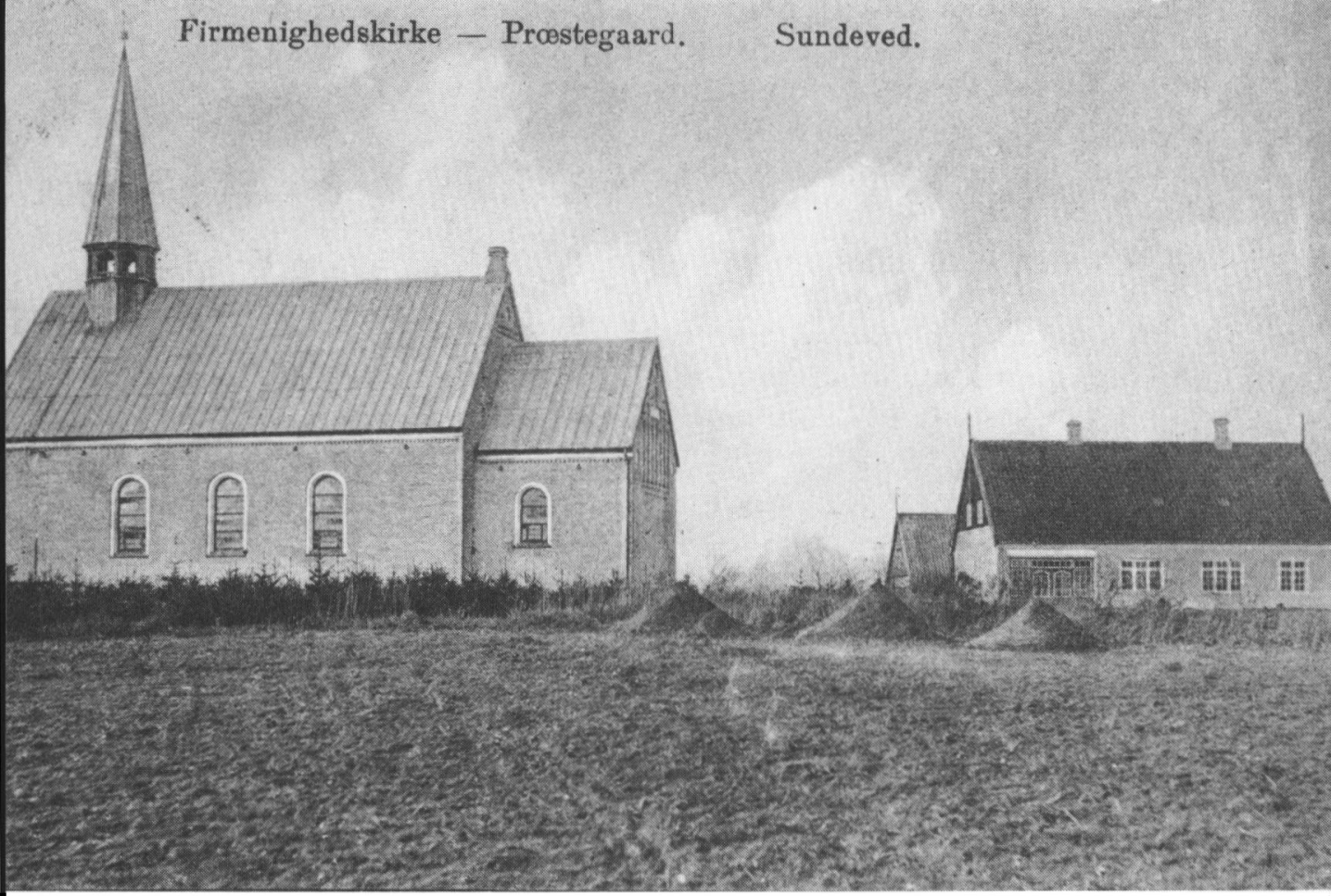

Sundeved frimenighedskirke og prastegård fotograferet kort efter 1904. Postkort i Historiske Samlinger, Aabenraa.

Kirken, som har Siddepladser til omtr. 250 Mennesker, var fyldt til sidste Plads.

Poulsen, Bovlund, holdt Indvielsestalen, Lycke ${ }^{34}$, Rødding, prædikede over Dagens Tekst, og Jørgensen ${ }^{35}$, Skærbæk, holdt Skriftetalen før Altergangen. Det føltes som et stort Savn af Menighedens Medlemmer, at Frimenighedspræst Thomsen, Haderslev, paa Grund af Sygdom ikke, som det havde været bestemt, kunde foretage Indvielsen, fordi han, som før omtalt i denne Redegjørelse, var den, der havde tilskyndet til at faa Kirken bygget. Der er blevet holdt Gudstjeneste i Kirken saa vidt muligt 2 Gange i hver Maaned, og Kirkebesøget har været over al Forventning godt. Frimenighedspræsterne Poulsen, Lycke og Jørgensen har hidtil skiftevis betjent Menigheden, medens R. Thomsen aldrig, paa Grund af vedvarende Sygdom, kom til at tale i vor lille, venlige Kirke. Han døde September 1905. 


\section{NOTER OG HENVISNINGER}

\section{Om udgivelsen:}

Andreas Andresens erindringer bringes her med enkelte forkortelser på grundlag af en afskrift i A.Andresens privatarkiv på Landsarkivet i Aabenraa, hvortil de er afleveret af Historisk Samfund for Sønderjylland. Der er især udeladt dele af de ofte meget detaljerede slagtshistoriske redegørelser, ligesom en del er udeladt om Andresens barndom, hans ophold i Danmark 1866-67 og om stormfloden i 1872. Et afsnit om børnenes sygdomme er heller ikke medtaget. Udeladelser markeres med tre prikker. Mindre dele af manuskriptet er tidligere publiceret af et barnebarn, Margrete Schultz i Sønderjyske Årbøger 1987 s. 123ff.

Personalhistoriske oplysninger er fra Dansk Biografisk Leksikon, Nedergaard: Dansk Præste- og Sognehistorie samt L.S. Ravn: Larerne i Nordslesvig ca. 1814-1920.

1. Peter Andresen, f. 1740, hjulmagersøn fra Dynt (A.Korse: Broagerlands Historie, I, 1945, s. 2lf.)

2. Hun var datter af gårdens tidligere ejer Jürgen Iversen, som havde købt gården i 1748 (Korse anf. sted).

3. En sættemand eller årtidsmand var men kones anden mand, som kun skal forestå ejendommen så længe, indtil den forste mands ældste søn kan overtage den « (Feilberg: Ordbog over jyske Almuesmål, III, Kbh. 1904-11).

4. Mads Vesterlund (1798-1868) var distriktslærer i Skelde 1830-62.

5. Peter Chr.Aug. Lammers var kun larer i Skelde i 1858.

6. Julius Carl Gerhard Schleppegrell (1811-72) var andenprast i Broager 1852-64.

7. Kristen Karstensen (1809-82) var forsteprast i Broager og provst for Sønderborg provsti 185764. Han er i dag mest kendt for sine hjemstavnsdigte, f.eks. "Alssangen« og "Længe nok har jeg bondepige været «.

8. Diedrich Joh. Fr. Holst (1839-1911) var lærer i Skelde 1862-1902.

9. Christen Wollesen (1806-?) var først andenpræst 1839-49 og derpå under Treårskrigen førstepræst 1849-50. Afsk. 1850.

10. Jørgen Stephensen (1791-1856) var førstepræst i Broager fra 1834, afsk. af den slesv.-hol. regering 1848 , genansat 1850 , prest til sin død i 1856.

11. Ludwig Andr. Reuter (1836-1905) var andenpræst i Broager 1864-83 og førstepræst 1883-1905. Tillige provst for Sønderborg provsti 1886-1902. Ernst Fr. Schuhmacher (1844-1928) var andenpræst i Broager 1888-1913.

12. Andresens kone hed Margrethe Vrang og var datter af gdr. Jørgen Vrang og hustru Marie i Egen.

13. Klapning er aftærsket halm (Ordbog over det danske Sprog).

14. Wienerfredens artikel 19 bestemte, at de personer, som var hjemmehørende $\mathrm{i}$ hertugdømmerne indenfor et tidsrum af seks år frit kunne vælge statsborgerskab i Danmark (optere for Danmark) og toldfrit udføre deres løsøre dertil. Fast ejendom $\mathrm{i}$ hertugdømmerne måtte de derimod beholde (Fr.von Jessen: Haandbog i det nordslesvigske Spergsmaals Historie, 1901, s. 225ff.)

15. Den her udeladte skildring af et typisk bryllup er bragt i Sønderjyske Årbøger 1987, s. 127.

16. Foreningen "Enigheden « i Flensborg, oprettet 1868, var en udpræget dansk forening med ca. 400 medlemmer. Den var meget aktiv og foranstaltede bl.a. demonstrationsudflugter til Danmark. Lukket af myndighederne i 1875 .

17. L. B.Poulsen (1840-1919) var fra 1879 til sin død frimenighedspræst i Bovlund og meget benyttet som foredragsholder, ikke mindst med emner hentet fra det grundtvigske kristendomssyn.

18. A.C.C. Holdt havde 1865-75 en privatskole for drenge i Flensborg. I skolen gaves der undervisning i dansk.

19. Gustav Johannsen (1840-1901) var en af de mest fremtrædende danske ledere i Flensborg og omegn og fra 1880-erne for hele Nordslesvig, 1881-84 og fra 1886 til sin død var han dansk rigsdagsmand i Berlin, fra 1888 tillige landdagsmand. 
20. Klaus Berntsen var 1873-84 og 1886-1926 medlem af Folketinget for Venstre og indenrigsminister 1908-09, konsejlspræsident (statsminister) 1910-13 og 1920-22 forsvarsminister.

21. I 1870-erne gennemførtes en omfattende matrikulering af jorden i Sønderjylland efter de preussiske principper, som bl.a. indebar, at jordens nettoudbytte (Reinertrag) blev vurderet.

22. Meningen er formodentlig, at det er lang tid siden, køerne sidst har kælvet.

23. Ved vandmejerimetoden nedkøledes mælken i vandbade for at fremme flødesætningen.

24. En drittel er lig en tredjedel, en otting lig en ottendedel tonde smor.

25. Gdr. C.P. Wolff (1842-1913) var en af de mest fremtradende foregangsmænd indenfor det nordslesvigske landbrug. 1868-1908 var han således formand for Den sundevedske Landboforening, 1900-08 tillige for Fælleslandboforeningen for Nordslesvig.

26. Hans Lassen (1831-96) fra Lysabild på Als var 1875-96 landdagsmand og 1881-84 rigsdagsmand i Berlin. Derudover havde han et utal af lokale tillidsposter.

27. På synoderne mødtes gejstlige og lægfolk for at drøfte den evangelisk-lutherske kirkes anliggender. Provstisynoden bestod af provsten, alle præsterne i provstiet og det dobbelte antal lægmænd, valgt af sognenes kirkekollegier (menighedsråd). Provinssynoden eller fællessynoden bestod af biskopperne over Slesvig og Holsten, 8 kongevalgte medlemmer, en reprasentant for det teologiske fakultet ved Kiels universitet samt af præster og lægmænd, valgt p̊ provstisynoderne. Jfr. von Jessen anf. værk s. 531f.

28. Henriette Gubi (1856-94) virkede i forste halvdel af 1890-erne som vandrelærerinde flere steder i Nordslesvig.

29. Andreas Hansen (1806-83), førstepræst i Broager 1864-83.

30. Hans Chr. Thiessen (1840-1915), andenpræst i Broager 1884-88.

31. Optanter var de, der $i$ henhold til Wienerfredens paragraf 19 havde valgt dansk statsborgerskab (opteret for Danmark), jfr. note 14. I henhold til Aabenraaoverenskomsten fra 1872 fik optanterne lov til at blive i Sønderjylland, men de kunne udvises, hvis de faldt myndighederne til besvær. I årene 1902-03 forsøgte myndighederne gennem det såkaldte poptantmageri« at stemple flere ledende dansksindede, der ellers blev anset for preussiske statsborgere, som danske statsborgere med henvisning til, at selv et kortvarigt ophold i Danmark 1866-67 var nok til at gore den optionserklæring, de dengang havde afgivet, men ikke effektueret ved permanent overflytning til Danmark, gyldig.

32. Jens Jessen (1852-1906) var fra 1882 til sin død redaktør af "Flensborg Avis«. Han var $\mathrm{i}$ årene 1874-76 lærer på privatskolen i Broager.

33. Rasmus Thomsen (1849-1905) var 1878-80 lærer på en privat skole i Bovlund, men mistede denne bestilling, da myndighederne lukkede skolen.

34. Nis P. Lycke (1842-1924), frimenighedspræst i Rødding 1889-1923.

35. J.L. Jørgensen (1862-1946), frimenighedspræst i Skærbæk 1899-1935. 